\title{
DA APLICAÇÃO DO CÓDIGO DE DEFESA DO CONSUMIDOR ÀS INSTITUIÇÕES FINANCEIRAS ${ }^{1}$
}

\author{
APPLICATION OF THE CONSUMER PROTFCTION CODE TO FINANCIAL INSTITUTIONS
}

\section{Cintia Rosu Pereira de Lima'}

\begin{abstract}
Resumo:
Este trabalho visa a estudar o tema específico sobre a aplicação das normas consumeristas aos contratos celebrados pelos consumidores com as instituições financeiras (Bancos). A problemática em torno deste tema deve-se ao fato de que desde 26 de dezembro de 2002 está em tramitação no Supremo Tribunal Federal uma Ação Direta de Inconstitucionalidade (ADIn n. 2.591) em que os Bancos dizem ser inconstitucional a aplicação do CDC às suas operações. Sendo assim é relevante a análise dos argumentos dos Bancos para refutá-los um a um. $\mathrm{E}$, por fim. pretende-se investigar algumas espécies de operações bancárias para comprovar a existência de relação de consumo, desde que os usuários destes produtos e serviços o façam como destinatário final.
\end{abstract}

Palavras-chave: Consumidor. Bancos. Ação Direta de Incostitucionalidade. Aplicação do CDC. Operações bancárias.

\begin{abstract}
:
This work intends to study the specific theme about the consumer law's application to the contracts celebrated by the consumer with the financial institution (Banks). The problematic about this subject is due to the fact that since December, $26^{\text {th }} 2002$ the Brazilian Supreme Court has been judging an Action in which the Banks stated that the application of the Brazilian Consumer's Protection Code to its operation is against the Brazilian Constitution. That's why it is important to study each statement of this action and to oppose one by one. And finally conclude this work intends to investigate some of the banks' operation to prove the existence of consumer relation, once the users of such products or services do so as a final addressee.
\end{abstract}

Keywords: Consumer. Banks. Action. Brazilian Constitution. Application of Brazilian Consumer's Protection Code. Banks`operation.

1. Introdução

Discutir se o Código de Defesa do Consumidor (CDC - Lei n. 8.078/90) é aplicado às relações de consumo com as instituições financeiras, e aos Bancos em especial, parece uma questão ultrapassada. Desde a elaboração do CDC, o lobby das

Estudo inicialmente (2002) desenvolvido em trabalho de Iniciação Cientilíca financiadu pela Fundação de Amparo à Pusquisa do Estado de São Paulo - FAPESP.

Doutoranda em Dircitu ('ivil pela Faculdade de Direito da I 'niversidade de São Paulo. 
instituições financeiras iniciou uma batalha vexatória, cuja finalidade é esquivarem-se dos princípios e normas de conduta da legislação consumerista. Movimento que não se observa nos países estrangeiros, tanto nos desenvolvidos quanto nos países em desenvolvimento. como se verá no item seguinte, o legislador destes países desde há muito tempo preocupa-se em proteger os consumidores dos perigos do crédito e. portanto, do truculento sistema financeiro.

Infelizmente, os juristas pátrios ainda discutem esta questão, que deveria estar há muito superada. Isto porque as instituições financeiras ainda alegam que a aplicação dos princípios e das normas de conduta do CDC às relações com estas travadas seria inconstitucional. $\mathrm{E}$, há dois anos atrás. juristas patrocinaram esta causa ingressando no Supremo Tribunal Federal (STF) com uma Ação Direta de Inconstitucionalidade (ADIN n. 2.591), ação esta, que para nossa surpresa, ainda está sub judice.

É justamente este contexto que faz esta discussão atual e relevante para alcançar, o que tanto se espera, ou seja, a pacificação desta simples questão de forma a garantir os princípios e objetivos da República Federativa do Brasil (arts. $1^{\circ}$ e $3^{\circ}$ da CF/88).

Ademais, na atual sociedade, caracterizada por ser complexa, ${ }^{2}$ massificada e "bancarizada" " esta última decorre do fenômeno da "bancarização". que o Direito norte-americano desde logo percebeu a submissão obrigatória dos cidadãos consumidores ao sistema financeiro. Assim, justifica-se a proteção destes individuos, que segundo Carlos Ferreira de Almeida ${ }^{5}$ os sistemas de mercado estão calcados na ideologia liberal, é o que se percebe da leitura dos tradicionais, hoje revogados pelo Código Civil de 2002 (CC/02 - 10.406, de 10 de janeiro de 2002). Código Civil (Lei n. 3.071. de $1^{\circ}$ de janeiro de 1916 - CC/16) e Código Comercial (Lei n. 556, de 25.06.1850 $-\mathrm{CCom})$.

CAMPILONGO, Celso Fernandes. O Direito na sociedade complexa. São Paulo: Max Limonad. 2000. p. 71: "Assim, quer por suas repercussões no espaço público quer por suas peculiaridades no espaço privado. 'a sociedade de organizaçōes". gradativamente, vai substiluindo a "sociedade de homens", com scirios riscos de perversão das funções do direito positivo, do Estado, da democracia e da intersubjetividade da vida social"

3 BENJAMIN, Antònio Herman de Vásconcellos e et al. Código Brasileiro de Defesa do ('onsumidor: 6. ed. Rio de Janeiro: Forense Universitária. 1999. p. 06: "O homem do século XX vive vem função de um modelo novo de associativismo: a sociedade de consumo (mass consumption society ou Konsumgesellschaft), caracterizada por um número crescente de produtos e serviços, pelo domínio do crédito e do marketing, assim como pelas dificuldades de acesso à justiça"

- Apud MARINS, James. Proteção contratual do CDC a contratos interempresariais, inclusive bancários. Revista de Direito do Consumidor. São Paulo, v. 18, p. 94-104, abr./jun. de 1996: "Antônio Herman nos ensina que se em algumas sociedades o nivel de 'bancarização' é muito elevado. no Brasil chega a ser quase absoluto se considerado que mesmo os cidadãos de mais baixo nivel econômico vèem-se implicados com o sistema bancário em virtude de contas vinculada a benefícios sociais [...]"

5 ALMEIDA. Carlos Ferreira de. Os direilos dos consumidores. Coimbra: Almedina, 1982. p. 11. 
Nestes sistemas pouca era a interferência estatal nas atividades econômicas, sendo que o modelo destas atividades estava calcado na propriedade e iniciativa privada.

Este comportamento estatal orientado pelo princípio da igualdade (formal) não levava em consideração as desigualdades reais entre os consumidores (vulneráveis, e muitas vezes, hipossuficientes) e as empresas (com alto poder econômico, técnico, social e etc).

Constatou-se, contudo, que na pós-modernidade, é inegável o pluralismo pós-moderno, em que a complexidade e dinâmica das relações sociais não possibilitam a antiga solução una e estática em que se estruturavam, os códigos tradicionais. Para harmonizar o Direito com as relações sociais modernas é necessária uma interpretação sistêmica, ou seja. "mais fluida, mais flexivel, a permitir maior mobilidade e fineza de distinções" 6

No que diz respeito às relações de consumo com instituições financeiras, c com os Bancos, em particular, não se pode negar a essencialidade dos serviços bancários, já que na sociedade atual todos se dirigem aos Bancos para satisfazerem suas necessidades pessoais, como recibo e depósitos de valores, pagamento de contas, etc.

Carlos Ferreira de Almeida, para exemplificar tal situação, utiliza a expressão "sujeitos à sujeição" no sentido de que os consumidores, estando em desvantagem sócio-econômica em face dos agentes econômicos. têm pouco poder de negociar efutivamente com estes. Na prática, a regras do negócio são basicamente impostas pelos mais fortes (os agentes econômicos).

Consoante este argumento. entende-se que as relações de consumo travadas com as instituições financeiras dão-sc através de contratos cativos de longa duração, ${ }^{8}$ pautado pela continuidade dos serviços prestados e catividade dos clientes, que não tem outro meio para ao qual recorrer, devido à essencialidade do crédito na sociedade de consumo atual. Em outras palavras, segundo a terminologia mais moderna a respeito, os contratos bancários podem ser definidos como contratos relacionais de consumo, ${ }^{9}$ caracterizado pelos múltiplos serviços integrados e combinados.

${ }_{6}$ Esta teoria foi desenvolvida por Erik Jayme, e trazida para o Brasil com a clareza e cientificidade da jurista Cláudia Lima Marques, em sua obra: MARQUES, Cláudia Lima; BENJAMIN, Antônio Herman V.: MIRAGEM, Bruno. Comentarios ao Código de Defesa do Consumidor: arts. $1^{\circ}$ a 74 -Aspectos Materiais. São Paulo: Revista dos Tribunais, 2003. p. 24-26.

AL.MEIDA, Carlos Ferreira de. op. cit. p. 13.

8 MARQUES, Cláudia Lima. Contratos bancários em tempos pós-modernos-primuiras reflexóes. Revista de Direilo do Consumidor, Sâo Paulo. v. 25. p. 19-38, jan./mar. 1998.

- MACEDO JR., Ronaldo Porto. Contratos relacionais do direito bancário. (Palestra proferida no 1" Simpósio Nacional de Direito Bancario, realizado em São Paulo de 06 à 08 de Julho de 2000 . Disponivel $\mathrm{em}$ : <http://www.cartamaior.uol.com.br/doutrina/exibe_artigo.asp?cd_artigo=77>. Acesso em: il jan. 2005. 
Desta forma o conteúdo ideológico do CDC está voltado à proteção dos consumidores, legalmente, tidos como a parte mais fraca da relação (art. $4^{\circ}$ do CDC), o que reclama do Estado-legislador uma tomada de posição no sentido de "retificar os abusos da sociedade de consumo" 10

A posição de alguns doutrinadores tem sido no sentido de defender a aplicação do CDC tão somente aos serviços bancários (obrigações de fazer), com por exemplo, os contratos de caixa de segurança ou cofres individuais, excluindo os produtos e contratos bancários (obrigações de dar), por exemplo, os contratos de empréstimos, de conta poupança, e ouros. " Todavia tal distinção não tem justificativa, vez que o CDC visa a tutelar as atividades desenvolvidas pelos fornecedores a título profissional.

Newton de Lucca $^{12}$ analisa a questão da aplicação do CDC às instituições financeiras, em específico, aos Bancos. Dizendo que o estatuto consumerista aplica-se aos Bancos diante da intenção do legislador, que deixou expresso no $\S 2^{\circ}$ do art. $3^{\circ}$ do referido diploma legal.

Portanto, o objeto desta pesquisa é justamente o de analisar de forma científica os aspectos pertinentes à discussão da aplicabilidade do CDC às instituições financeiras.

2. A proteção dos consumidores em face das instituições financeiras no Direito Comparado

O consumidor tem recebido regulamentação específica pela comunidade internacional de um modo geral, principalmente. dos países desenvolvidos, como os membros da Organização Mundial do Comércio, Comunidade Européia, Estados Unidos, Canadá.

Só este fato reflete que há muito se percebeu que os cidadãos consumidores estão em desvantagem em face das grandes e multinacionais empresas, que se espalharam pelo mundo, dominando o sistema da atual economia globalizada. Se há fragilidade dos indivíduos que necessitam dos produtos e serviços oferecidos por estas multinacionais, esta se acentua quando os consumidores vêem-se obrigados a

1 NOBRE JÚNIOR., Edilson Pereira. A Proteção contratual no Código do Consumidor e o âmbito de sua aplicação. Revista de Direito do Consumidor. São Paulo, n. 27, p. 57-77, jul./set. 1996.

1" DALLAGNOL JR., Antônio Janyr. Direito do consumidor e serviços bancários e financeiros - aplicação do CDC nas atividades bancárias. Revista do Direito do Consumidor, v. 27. p. 07-17, jul./set. 1996.

12 A aplicação do Código de Defesa do Consumidor à atividade bancária. Revista de Direiro do Consumidor. São Paulo. v. 27, p. 78-87, jul./set. 1996. 
aderirem às cláusulas gerais dos contratos de adesão impostas pelas instituições financeiras.

Portanto, vê-se que, nestes países, o consumidor -- ou seja, a pessoa que recorre ao crédito para satisfazer a maior parte de suas necessidades ou despesas realizadas para a compra de um carro, de eletroeletrônicos, eletrodomésticos, etc ${ }^{13}$ recebe do legislativo constante proteção conforme se pretende demonstrar neste item.

A princípio, os Estados Unidos, apesar de se estruturar pelo sistema dos precedentes da Common Law, há diversas leis específicas que visam à proteção dos consumidores que necessitam de créditos ou financiamentos junto às instituições financeiras. Citando alguns exemplos: Consumer Credit Protection Act, Consumer Leasing Act, Credit Repair Organization Act, Electronic Fund Transfer Act, Equal Credit Opportunity Act, Fair Credit Billing Act e Truth in Lending Act, todas estas leis foram incorporadas ao U.S. Code, nos títulos 12 e $15 .{ }^{14}$ A ênfase destas normas é a proteção do consumidor impondo normas de conduta (obrigações e deveres) às instituições financeiras.

No Canadá, as instituições financeiras, também, submetem-se às regras de conduta impostas pelo, coincidentemente, denominado de Consumer Credit Protection $A C l,{ }^{15}$ cujo objetivo é o reequilibrio da relação contratual entre consumidores e instituições financeiras. Equilíbrio que se impõe mediante a intervenção do Estadolegislador reconhecendo a fragilidade destes indivíduos que se submetem às condições de negociação que lhes são impostas pelas instituições financeiras.

Há inúmeras leis francesas que foram incorporadas ao Code de la Consommation, cuja finalidade é a proteção do consumidor contra os "perigos do crédito" assegurando, desta forma o equilíbrio contratual.

A doutrina francesa também se preocupa com esta matéria. Calais-Auloy ${ }^{16}$ aponta que um dos fatores da situação de vulnerabilidade dos consumidores nos contratos bancários e de crédito é o fato de não haver chance de o consumidor discutir as cláusulas contratuais, submetendo-se à cobrança das altas taxas e dos juros extorsivos. E define o âmbito de aplicação das regras protetivas dos consumidores com relação aos contratos de crédito: ${ }^{17}$

As disposições do capitulo sobre o crédito ao consumo aplicam-se 'a toda operação de crédito, bem como à sua garantia eventual, concedido a titulo habitual para pessoas

1) CALAiS-AuloY, Jean et al. op. cit., p. 309.

it Site da Federal Trade Comission. Disponivel em: <http://www.ftc. gov Acesso em: 29 jan. 2005.

is Disponivel em: <http://www.gov.pe.ca/law/statutes>. Acesso im: 10 jan. 2005.

16 CALAIS-AULOY, Jean. op. cit. p. 310.

17 Id. Ibid. p. 323. Tradução livre. 
físicas ou morais, seja a título oneroso ou gratuito ${ }^{*}$ (art. $311-2$, al. ler.).

E cita os seguintes exemplos: vendas a crédito, os empréstimos pessoais, os empréstimos acessórios, cartão de crédito, o crédito renovável, etc.

Tanto a doutrina, quanto a jurisprudência francesas não discutem a enfadonha argüição sobre a não aplicação das normas do C'ode de la Consommation às instituições financeiras, sendo perfeitamente aplicáveis as regras gerais deste Código constantes dos artigos L. 121-1 e seguintes. Havendo, inclusive, diversas outras leis extravagantes que conferem uma proteção mais eficaz aos consumidores: Loi du 28 décembre 1966. que trata da proibição da usura, incluída no Code de la Consommation nos artigos L. 313-1 ao L.313-6; a Loi Scrivener (Loi 78-22 du 10 junvier 1978) relativa ao direito à informação e à proteção dos consumidores no domínio de certas operações de crédito, esta lei foi inspirada pelos precedentes ingleses e alemães, e, também, integrada ao Code de la Consommation (arts. L.311-1 à L.311-37); a Loi du 24 janvier 1984 que criou um comitê de regulamentação bancária e uma comissão bancária, além de um comitê consultivo, para que os consumidores fossem efetivamente ouvidos.

O Direito Comunitário europeu tutela os direitos dos consumidores nos contratos de crédito através da Diretiva da CE de 22 de dezembro de 1986, obrigando todos os Estados membros a protegerem os consumidores contra os "perigos do crédito".

A título de exemplo, Portugal regula os direitos básicos dos consumidores através da Lei n. 29/81, de 22 de agosto e pelo Decreto-Lei n. 446/85, de 25 de outubro, e o Tribunal de Justiça de Portugal ${ }^{18}$ vem decidindo também segundo os termos da Diretiva supra mencionada:

Ementa: "Directivas 87/102/CEE e 90/88/CEE Crédito
ao consumo Taxa de juro variável Renovação do
contrato Taxa amual efectiva global Falı de
informação ao consumidor - Prazo de caducidade
Compatibilidade com o direito comunitário»" Neste
julgado foi decidido que: "A Directiva 87/102/CEE do
Conselho, de 22 de dezembro de 1986 , relativa à
aproximação das disposições legislativas. regulamentares e
administrativas dos Estados-Membros relativas ao crédito
ao consumo, com a redacção yue lhe foi dada pela
Directiva 90/88/CEE do Conselho, de 22 de fevereiro de
1990, impõe, previamente a cada renovação, cm condições
inalteradas, de um contrato de crédito com duração fixa,
concedido sob a forma de abertura de crédito utilizável por

18 Acórdão do Tribunal de Justiça de Portugal (Quinta Secção), de 04 de março de 2004. Processo C-264/02. Cofinoga Mérignac SiA vs Sylvain Sachithanathan. Disponivcl em: - http:i/www.stj.pl>. Acesso cm: 11 jan. 2005. 
fracções, com atribuição de um cartão de crédito, reembolsável em mensalidades e cuja taxa de juro foi estipulada variável, que o mutuante é obrigado a informar por escrito o mutuário da taxa anual de encargos efectiva global em vigor, bem como das condições em que esta última pode ser modificada.

Na Alemanha, a proteção do consumidor também não é questionada, havendo uma lei específica sobre crédito ao consumidor de 1991 (Gesetz über Verbraucherkreidite), incluida no $B G B$, art. 461 .

Por estes exemplos, vê-se que é totalmente razoável, e necessária, a proteção do consumidor contra as armadilhas dos sistemas financeiros de concessão de crédito, havendo uma atenção do legislador neste sentido nos países econômica e industrialmente desenvolvidos. Não é aceitável, que o Brasil, um país em desenvolvimento, que tem um Código de Defesa do Consumidor exemplar (muito embora não haja nenhuma lei específica protegendo os consumidores contra os perigos do crédito, como há na Europa, Estados Unidos e Canadá), ande na contra-mão, retrocedendo no tempo. para excluir a aplicação das normas gerais de proteção do consumidor do $\mathrm{CDC}$ às instituições financeiras. Assim, no próximo item é pertinente um estudo mais detalhado da ADIN n. 2.591 que discute esta questão.

3. Estudo da Ação Direta de Inconstitucionalidade n. 2.591

Encontra-se em tramitação no Supremo Tribunal Federal uma Ação Direta de Inconstitucionalidade, a ADIn n. 2.591, de 26 de dezembro de 2002, que visa a não aplicação das normas do CDC às instituições financeiras, alegando ser inconstitucional a expressão do $\S 2^{\circ}$ do art. $3^{\circ}$ do CDC: "[...] inclusive as de natureza bancária. financeira, de crédito e securitária"

Um dos advogados da Consif (Confederação Nacional do Sistema Financeiro), Arnold Wald, desde 1991, um ano após a promulgação do CDC. já afirmava a não aplicação deste estatuto legal às instituições financeiras, muito embora ter sido o CDC expresso quanto a isto no $\S 2^{\circ}$. art. $3^{\circ} .^{10}$

Os advogados que estão promovendo esta ação sustentam no decorrer de sua petição que o objetivo da ação é apenas o de declarar a inconstitucionalidade da expressão supra mencionada.Todavia, ocorrerá a inconstitucionalidade por derivação, e conseqüentemente, todos os dispositivos do CDC não se aplicarão às entidades

19 WALD. Arnold. O direito do consumidor e suas repercussões em relação às instituiçōes financciras. Revista dos Tribumais, n. 666, p. 07-17. abr. 1991. 
realizadoras de atividades de natureza financeira e creditícia, sem a necessidade de impugnação específica de cada uma de suas disposições.

Um primeiro argumento desta ação é que o CDC criou novos e maiores encargos e obrigações às instituições financeiras ao imputar-lhes mais responsabilidades. Desta forma, sustentam Arnold Wald, Ives Grandra S. Martins e Luiz Carlos Bettiol (advogados da Consif) que o estatuto consumerista viola o princípio da razoabilidade, sede material do devido processo legal (art. $5^{\circ}$, LIV, da Constituição Federal). ${ }^{20}$

Sendo justamente o contrário, isto é, o CDC norteia-se por diversos princípios, dentre eles, o princípio da razoabilidade e da igualdade real. Portanto, quanto a esta alegação cumpre ressaltar que, na verdade, a não aplicação das normas de conduta do $\mathrm{CDC}$ às instituições financeiras é que seria uma violenta violação aos princípios da razoabilidade e da igualdade real (art. $5^{\circ}$. caput da $\mathrm{CF} / 88$ ). Senão vejamos, a doutrina que analisa com profundidade o princípio da razoabilidade diz:

Razoabilidade é a qualidade do que é razoável, ou scja, aquilo que se situa dentro de limites aceitáveis, ainda que os juizos de valores que provocaram a conduta possam dispor-se de forma um pouco diversa. Ora, o que é totalmente razoável para uns pode não o ser para outros. Mas, mesmo quando não o seja, é de reconhecer-se que a valoração se situou dentro dos standards de aceitabilidade. ${ }^{21}$

Fazendo um paralelo entre a doutrina do Direito Administrativo e o Direito do Consumidor, não é razoável, por extrapolar os limites padrões de aceitabilidade, que o CDC não seja aplicado às instituições financeiras, uma vez que este setor é imprescindível à subsistência no atual mercado o que reclama do Poder Público uma maior atuação neste sentido, impondo limites à atuação das instituições financeiras e impondo-lhes deveres e obrigações conexas. Aliás o art. 170, inciso V, da CF/88 traz como um dos princípios da ordem econômica a defesa do consumidor.

Tudo isto nos leva a uma infeliz conclusão: para quê tanto trabalho por parte das instituições financeiras para não se obrigarem às normas de conduta e princípios elencados no CDC? Por quê tais regras oneram por demais as instituições financeiras, e as demais empresas não?

A resposta é patente: porque as instituições financeiras querem atuar no mercado sem obedecer a nenhuma regra, para assim obter a maximização de seus lucros.

20 Segundo a Petição Inicial da ADIn n. 2.591, em tràmite no STF desde 26/12/200।, quando foi interposta pelos supra mencionados advogados, os quais estão representando os interesses da CONSIF (Confederação Nacional do Sistema Financeiro).

21 Carvalho filho, José dos Santos. Mamual de Direito Administrativo. 10. ed. Rio de Janeiro: Lumen Juris. 2003. p. 23-26. 
Assim dentro da racionalidade do pensamento dos economistas, o CDC seria uma "norma distorciva". 22 já que a norma jurídica interfere em um equilíbrio de mercado eficiente que atende às propriedades do "ótimo de Pareto"

Porém a auto-regulamentação do mercado almejada pelos economistas traz injustiças sociais e flagrante desequilíbrio real entre as partes, no caso. instituições financeiras e consumidores, vez que estes últimos subordinam-se aos surtos especulativos do mercado na bolsa de ações ou no mercado cambial.

Não se pode deixar tal interesse vencer, pois nos países desenvolvidos, o Estado atua intensamente em prol da efetivação dos direitos dos cidadãos consumidores, que através do dirigismo contratual impõe diversos deveres e obrigações morais e éticas às instituições financeiras como fora detalhado no item anterior.

Assim, deve prevalecer esta ótica social do mercado: "A ordem de mercado no Direito Social torna-se mais claramente uma ordem do mercado social na qual os valores sociais desempenham importante função na determinação dos conteúdos do contrato" 23

Não é razoável que os Bancos sejam imunes às sanções civis, administrativas, e por vezes, penais decorrentes da má prestação de serviços como ocorre com outros prestadores de serviços ou fornecedores de produtos no mercado de consumo. Mesmo porque se constata que nos contratos bancários há inúmeras falhas na informação sobre custos de tarifas bancárias, prazos para aplicação e custos decorrentes do mau planejamento econômico, ${ }^{24}$ o que causa enorme prejuízo aos consumidores que necessitam do crédito e destes contratos e serviços, nada mais razoável que estas empresas, assim como as demais, sejam obrigadas a respeitar o direito à informação plena aos consumidores.

Alegam os patrocinadores dos interesses das instituições financeiras, que o Manual de Normas e Instruções do Banco Central (MNI) distingue as atividades bancárias em operações e serviços de Banco. As operações bancárias são, portanto, divididas entre ativas e passivas.

Diante desta divisão alegam estes que o CDC referiu-se tão somente aos serviços bancários, excluindo-se portanto as operações bancárias (obrigações puras de dar). E se justificam afirmando que o objeto das operações bancárias é o dinheiro, e não pode ser tido como objeto de consumo, já que é um elemento de troca. Nesta linha de raciocínio, os usuários dos serviços bancários não podem ser considerados como

ARIDA, Pérsio. Direito e Economia. FGV/Edesp, São Paulo, visão revisada em 10.10.2003. p.03.

MACEDO, Ronaldo Porto. op. cit. p. 06-07 de 22.

Id. Ibid.. p. 10 de 22. 
consumidores, pois não utilizam o dinheiro como destinatário final, mas sim como instrumento de troca, ou seja, para adquirir outros bens.

Entretanto tais alegações não procedem, vez que o dinheiro é um bem juridicamente consumível diante do art. 86 do CC/02.

Outro argumento levantado pelos patrocinadores da ADIn n. $2.591 \mathrm{diz}$ respeito ao fato de ser o CDC uma lei ordinária e, por isso, não pode afrontar a Magna Carta, que no caput do art. 192 da CF/88, reservou à lei complementar a regulamentação do Sistema Financeiro Nacional, que abrange os serviços de natureza bancária.

Não procede tal alegação, quanto a isto, Newton de Lucca ${ }^{25}$ diz que hierarquicamente, as leis complementares são superiores às leis ordinárias, mas isto não significa que ambas não possam conviver harmoniosamente.

Para ressaltar esta questão, nunca se questionou a aplicabilidade da Lei n. 6.404, de 15.12.1976 aos Bancos que por lei ordinária são constituídos sob a forma de Sociedades por Ações; ou a Lei n. 6.385, de 07.12.1976, também ordinária, permitindo aos Bancos que abram seu capital, e, portanto, sujeitam-se às normas sobre as Sociedades Abertas.

Cláudia Lima Marques ${ }^{26}$ alerta-nos para o possível "efeito bola-de-neve", ou seja, se esta alegação vencer, abriria caminho para se discutir a aplicação do Código Civil de 2002, que é lei ordinária (Lei n. 10.406. de 10.01.2002) às instituições financeiras.

Assim. percebe-se o equívoco da ADIn, ou seja, que a lei complementar deve regular os Sistema Financeiro Nacional e a organização, o funcionamento e as atribuições das instituições financeiras.

No que diz respeito à classificação das normas jurídicas, ${ }^{27}$ tem-se as normas jurídicas de organização, aquelas que fixam as atividades administrativas, ou seja, regulam a estrutura e o funcionamento de órgãos; já as normas de conduta, por sua vez, estruturam-se de uma forma singular impondo uma conduta sob uma possivel sanção para o caso de descumprimento, e desta forma, elas visam à disciplina do comportamento dos indivíduos na sociedade.

DE LUCCA, Newton. op. cit., p. 85.

26 MARQUES, Cláudia Lima. Contratos no Código de Defesa do Consumidor: o novo regime das relaçōes contratuais. 4. ed. rev. atual. c ampl. São Paulo: Revista dos Tribunais, 2002. p. 441.

27 REALE, Miguel. Liçōes preliminares de Direito. 24. ed. São Paulo: Saraira, 1998. p. 98-102. 
Desta feita, Cláudia Lima Marques ${ }^{28}$ destaca que a expressão contida no $\S$ $2^{\circ}$ do art. $3^{\circ}$ do CDC é uma definição legal, portanto, uma regra de conduta auxiliar, trazendo uma definição legal que, conseqüentemente, delimita o campo de aplicação do CDC, e não-regula ou organiza, em hipótese alguma, o sistema Financeiro Nacional. Este, por sua vez, requer normas de organização, como as normas presentes nas leis $\mathrm{n}$. $4.595 / 64,4.728 / 65$ e $6.385 / 76$. Sendo assim, deve-se fazer uma interpretação conforme da Constituição Federal (verfassungskonform Auslegung) mantendo uma coerência.

Neste mesmo sentido foi o parecer do Procurador Geral da República, Geraldo Brindeiro: ${ }^{29}$

Não há, pois, invasão de competência alguma; mostra-se perfeitamente possivel a coexistência entre a lei complementar reguladora do Sistema Financeiro Nacional e o Código a que devam sujeitar-se as instituições bancárias, financeiras, de crédito e de seguros, como todos os demais fornecedores em suas relações com os consumidores. [...] De outro lado, a existência de um Código de Defesa do Consumidor, com incidência nas relações entre instituições financeiras e consumidores, não subtrai ao Banco Central o ônus de disciplinar a prestação de serviços bancários a clientes e ao público em geral, como previsto na legislação pertinente.

Sustentam, também, os advogados desta ADIn que "todos os comandos do art. 192 da Constituição dependiam de lei de concreção, e, inclusive o $\S 3^{\circ}$ do art. 192 da $\mathrm{CF}$, que estabelece em $12 \%$ a taxa máxima de juros anuais, depende de regulamentação por uma lei complementar. Uma vez que esta regulamentação não foi feita, não se pode fazer uso desta determinação constitucional" (disposição revogada pela EC n. 40)

O CDC em momento algum visa a regulamentar a questão dos juros retributivos, que antes da Emenda Constitucional n. 40, de 29.05.2003, eram constitucionalmente limitados em $12 \%$, o que o CDC dispõe é sobre a questão dos juros moratórios, em seu art. $52, \S 1^{\circ}$ que os fixa em $2 \%$ do valor da prestação devida.

Quanto à questão da antiga limitação dos juros pela $C F / 88$, hoje não existe mais, já que a Fmenda Constitucional n. 40/03 revogou os parágrafos do art. 192 da

28 MARQUES, Cláudia Lima. op. cit., p. 440-441; MARQUES, Cláudia Lima; BFNJAMIN, Antônio Herman V:; MIRAGEM, Bruno. Comentários ao Código de Defesa do Consumidor: arts. $1^{\circ}$ a 74 Aspectus Materiais. São Paulo: Revista dos Tribunais, 2003. p. 96-99. Parecer para a ADIn 2.591 a pedido do Brasilcom. Disponivel em: <http://www.brasilcom.org.br>. Acesso em: 10 dez. 2004.

29 BRINDEIRO, Geraldo. Parecer à ADIn n. 2.591. Disponivel em: <http://www.brasilcom.org.br >. Acesso em: 20 dez. 2004. No mesmo sentido: PFEIFFER, Roberto Augusto Castellanos. Constitucionalidade da submissào dos serviços de natureza bancária. financeira. de crédito e securirária ao Código de Defesa do Consumidor. Disponivel em: <http: www.brasilcom.org.br>. Acessado em: 05 jan. 2005: afirma o autor que o campo material da lei ordinária é verificado por exclusão, o que denomina de campo residual, entendido como o "campo que nāo foi entregue expressamente ao legislador complementar. nem ao editor do decreto legislativo e das resoluções", não havendo, portanto, hierarquia entre leis complementares e leis ordinárias. 
CF/88. O STF já tinha se posicionado no sentido de que aquela norma não tinha aplicação imediata, quando julgou a ADIn n. 4.

Neste particular venceu o argumento racional dos economistas que afirmavam que a limitação em $12 \%$ dos juros fixados pelo $\S 3^{\circ}$ do art. 192 da CF/88 foi um motivo de "desintermediação financeira e fuga para ativos reais, com conseqüente desvalorização da moeda, redução da poupança e do investimento. O entendimento do dispositivo como não auto-aplicável evitou uma crise econômica que provavelmente teria sido de grande magnitude" 30

Volto a ressaltar aqui que nos Países desenvolvidos europeus e os Estados Unidos da América, a proteção dos consumidores, em especifico, a proteção dos consumidores contra os "perigos do crédito" 31 não foi um fator de insegurança econômica e fuga de capitais destes países. Por quê o seria no Brasil?

Outro embasamento desta ADIn refere-se ao fato de que há uma distinção entre consumidor de produtos e usuários de serviços e clientes de instituições financeiras devido às peculiaridades deste sistema. É sustentado na ADIn que as instituições financeiras trabalham com dinheiro de terceiros, com retenção de valores ("float"). Sendo assim, está configurada a remuneração indireta, e o $\mathrm{CDC}$, no $\S 2^{\circ}$ do art. $3^{\circ}$ conceitua serviço aquele prestado mediante remuneração, sendo indiferente se a remuneração for direta (mediante taxas) ou indireta (usando-se de dinheiro de terceiros, as instituições financeiras obtêm lucros).

A função social primordial das instituições financeiras é a concessão de crédito e a prestação de outros serviços essenciais à subsistência em uma sociedade "bancarizada" Esta importância já foi ressaltada por diversas vezes pela doutrina, a saber:

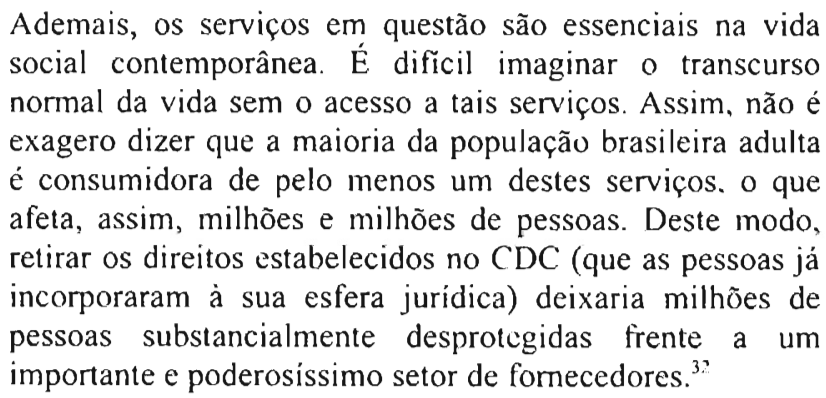

\footnotetext{
30 ARIDA, Pérsio. Direito e Economia. FGV/Edesp, São Paulo, visão revisada em 10.10.2003.p. 12.

3 Esła expressão é, inclusive, utilizada pelas Diretivas da Comunidade Européia, legislaçōes francesas, etc.

32 PFEIFFER, Roberto Augusto Castellanos. op. cit.
} 
No estado atual do julgamento da ADIn n. 2.591. tem-se apenas a manifestação dos ministros Carlos Velloso (relator) e Néri da Silveira pela improcedência da ação, emprestando ao $\S 2^{\circ}$ do art. $3^{\circ}$ do C.DC interpretação conforme a $\mathrm{CF} / 88^{33}$

Concluímos que esta ADIn nada mais é do que o reflexo dos interesses das instituições financeiras em cada vem mais aumentar seus lucros em detrimento dos consumidores ("sujeitos à sujeição") dependentes destes serviços para sobreviver ao fenômeno social da "bancarização" Em um sistema capitalista, o lucro é o que movimenta a sociedade, que segundo, Georges Ripert "Não existiria somente estrutura capitalista, mas espírito e moral capitalistas. Esse espírito e esta moral seriam caracterizados pela busca de um lucro ilimitado" E, por isso, deve ser sustentado um lucro razoável às instituições financeiras para não onerar demais os cidadãos que se utilizam destes serviços, que nos dias atuais, são essenciais.

\section{4. Âmbito de aplicação do CDC: elementos constitutivos da relação de consumo}

O CDC visa a regular tão somente as relações de consumo, isto é, aquelas que ocorrem entre fornecedor e consumidor, cujo objeto é um produto ou serviço. Todos estes elementos constitutivos da relação de consumo são definidos pelo CDC e, portanto, delimitam o âmbito de aplicação dos dispositivos deste diploma legal.

Leães $^{35}$ aponta que a relação jurídica é uma relação da vida social disciplinada pelas normas jurídicas. A relação de consumo nada mais é que uma relação "jurídica específica" Isto porque é uma relação jurídica, ou seja, é o vínculo entre duas partes (já definidas por lei: consumidor e fornecedor) por meio do qual se pretende adquirir um produto ou um serviço fornecido por um profisssional.

Conclui-se que em uma relação de consumo devem estar presentes os elementos subjetivos (fornecedor e consumidor), os elementos objetivos (produtos e serviços), bem como o elemento finalístico ou intríseco da relação que é a destinação final. Na ausência de quaisquer destes elementos não poderá ser tida comó uma relação de consumo para fins de aplicação dos dispositivos do CDC.

$\mathrm{O} C \mathrm{CD}$ traz conceitos fundamentais nos arts. $2^{\circ}$ e $3^{\circ}$ e seus parágrafos, respectivamente, a definição de consumidor padrão, de fornecedor e de serviços e produtos. Legislações como o Code de la Consommation (Lei n. 93.949 de 26 de julho

3) Disponivel em: http://www.stf.gov.br>. Acessu em: 21 jan. 2005.

3 RIPERT, Georges. Aspectos juridicos do capitalismo moderno. Tradução Gilda G. de Azevedo. São Paulo: Livraria Editora Freitas Bastos, 1947. p. 341.

35 LEÃES, Luiz Gastão Pacs de Barros. As relações de consumo e o crédito ao consumidor. Revista de Direito Mercantil, n. 82, p. 13-23, abr./jun. 1991. p. 15. 
de 1993) não traz a definição de consumidor, tarefa esta delegada aos doutrinadores especializados no assunto.

Maria Antonieta Zanardo Donato ${ }^{36}$ vislumbra duas contribuições das definições trazidas pelos primeiros artigos do CDC, a saber: 1. serviu de base para uma melhor assimilação e compreensão das normas do Estatuto; e 2. evoluiu à sedimentação jurisprudencial. Sendo assim, a técnica de definir estes conceitos fundamentais de um "Direito Novo" foi adequada e efetivou os dispositivos do CDC, impedindo que possíveis disparidades juridicas conduzissem à incerteza jurídica.

Em síntese, a doutrina aponta três elementos constitutivos da relação de consumo: 1. elemento subjetivo; 2. elemento objetivo; e 3 . elemento teleológico ou finalístico, que compreenderia a destinação final, ou seja, a retirada do produto ou serviço do mercado de consumo. ${ }^{37}$ Vejamos então cada um destes elementos.

\subsection{A figura juridica do consumidor}

Este elemento da relação de consumo deve ser identificado pelo juiz diante do caso concreto. quando este utilize os produtos e serviços como destinatário final (elemento teleológico), o que equivale dizer para proveito próprio e de sua família.

Um posicionamento interessante de Leães ${ }^{38}$ é no sentido de observar dois elementos na definição dada pelo art. $2^{\circ}$ do CDC, a saber: elemento positivo, ou seja, a satisfação das necessidades do consumidor e de sua família (função econômica); e elemento negativo, isto é, a destruição dos bens adquiridos para tal fim.

$\mathrm{O}$ CDC utiliza meios de equiparação para abranger um maior número de individuos na figura jurídica do consumidor. Em outras palavras, o art. $2^{\circ}$ traz o conceito padrão de consumidor, mas em outros dispositivos, a lei agrega outros tipos de consumidores por equiparação, como se verá a seguir.

Os conceitos por equiparação visam à proteção de pessoas, ainda que estas não tenham relação contratual de aquisição de produtos ou prestação de serviços diretamente com os fornecedores destes. ${ }^{39}$

36 DONATO, Maria Antonieta Zanardo. Proteção ao consumidor: conceito e extensão. São Paulo: Revista dos Tribunais, 1993. p. 64.

37 Id. Ibid., p. 65-66.

38 LEÃES, Luiz Gastâo Paes de Barros. op. cit., p. 16.

39 ZANELlato, Marco Antônio. Considerações sobre o conceito juridico de consumidor. Rcvista Estratégica (Revista da Faculdade de Administração FAAP e do FAAP - MBA). v. I. n. 2, p. 34-45, jul.iset., 2002. p. 35. 
Diante desta finalidade de ampla proteção, James Marins ${ }^{40}$ defende a extensão dos conceitos de consumidor dos arts. 17 e 29 do $C D C$, que logo serão abordados, às empresas que sofreram dano decorrente de vício do produto ou serviço ou expostas às práticas comerciais. Fundamenta seu posicionamento dizendo que a finalidade da lei foi justamente criar tais exceções para dar maior proteção ao maior número de direitos violados possível. Assim, conclui que onde o legislador estabeleceu exceções não cabe ao juiz revogá-las ou desconsiderá-las.

Em um primeiro momento, a figura jurídica do consumidor é definida pelo art. $2^{\circ}$ do CDC: "toda pessoa física ou jurídica que adquire ou utiliza produto ou serviço como destinatário final" este é, portanto, o conceito padrão ou "Standard" assim indicado pela doutrina e jurisprudência.

A questão polêmica desta definição diz respeito às pessoas jurídicas. São elas passiveis de serem consumidores ou não?

Quanto a esta questão divergem a doutrina e a jurisprudência. Pasqualotto $^{41}$ entende que as normas do CDC destinam-se à proteção do mais fraco, sendo que a hipossuficiência deve estar presente para que se possa aplicar a proteção do consumidor. Este autor é a favor de um conceito aberto de consumidor, e que, portanto, seria caracterizado no caso concreto quando for efetivamente o destinatário final do produto ou serviço, o que fatalmente permitiria uma maior integração interpretativa do Estatuto em estudo.

Ressalta-se a posição do jurista francês Jean Calais-Auloy ${ }^{42}$ que afirma que para a correta análise do consumidor deve-se ter em vista a utilização do produto ou serviço para a satisfação de uma necessidade pessoal ou familiar, ou seja, excluindo-se o uso profissional dos bens, independentemente de ser uma pessoa física ou jurídica.

Há que se destacar que certos doutrinadores finalistas ${ }^{43}$ defendem que 0 conceito de consumidor pode ser estendido às pessoas jurídicas de pequeno porte (como as pequenas e médias empresas e os profissionais liberais). tendo em vista a vulnerabilidade destes quando atuem "fora de seu campo de especialidade" Neste caso, é necessário que se comprove a efetiva hipossuficiência das pessoas jurídicas para

to MARINS, James. Proteção contratual do CDC a contratos interempresariais, inclusive bancários. Revista de Direito do Consumidor, São Paulo, v. 18, p. 94-104, abr./jun. de 1996.

^PASQUalotTO. Adalberto. Conceitos fundamentais do Código de Defesa do Consumidor. Revista dos Tribunais, São Paulo, n. 666, p. 48-53, abril 1991.

t2 CALAIS-AULOY. Jean. op. cit., p. 09.

¿3ANELLATO, Marco Antônio. op. cit. p. 40; MARQUES. Cláudia Lima. Contratos no Código de Defesa do Consumidor: o novo regime das relações contratuais. 4. ed. rev. atual. e ampl. São Paulo: Revista dos Tribunais, 2002. p. 248. 
justificar a aplicação do CDC, cuja finalidade é justamente a de reequilibrar uma relação jurídica entre desiguais (hipossuficiência técnica, econômica, jurídica, etc.).

Arnold Wald ${ }^{44}$ afirma que não há nenhum impedimento de ser uma pessoa jurídica consumidor, basta que para isso ela contrate bens ou serviços, sem quaisquer ligação direta ou indireta com a sua atividade básica (profissional).

Completando este raciocínio, Leães ${ }^{45}$ aponta que apesar de certos doutrinadores não conferirem proteção aos consumidores intermediários (pessoas jurídicas), esta proteção será lícita quando estes consumidores atuarem "à margem de sua atividade empresarial", este, aliás, tem sido o entendimento predominante no direito comparado. De forma que se devem distinguir os bens que a empresa adquire a título de insumo (para repassar ao mercado de consumo), dos bens adquiridos pela empresa para uso privado. Neste último caso, para parte da doutrina, haveria a proteção do consumidor pessoa jurídica (empresa), uma vez que se submeteu aos controles do meio de produção dos fornecedores daqueles bens.

Posição interessante de Donato ${ }^{46}$ que afirma que quanto ao enquadramento das pessoas jurídicas no conceito de consumidor deve-se levar em conta se o produto e serviço por elas adquirido é "imprescindivel ou indispensável" para sua atividade ounão. Na primeira hipótese, não seria lícito aplicar as normas do CDC, já que este consumidor, pessoa jurídica fatalmente repassará estas despesas ao consumidor. $\mathrm{Na}$ segunda hipótese, podem-se aplicar as normas em defesa do consumidor, pois não sendo essencial à atividade empresarial é considerado um bem de consumo. Mas para isso deve-se reconhecer a vulnerabilidade destas pessoas jurídicas quando estiverem no papel de consumidor.

A Autora faz uma análise pormenorizada quanto a isto, e conclui que a vulnerabilidade técnica é possivel aos consumidores profissionais ou às pessoas jurídicas, quando atuarem fora de seu campo profissional. Todavia a vulnerabilidade jurídica, presume-se não possivel, tendo que neste caso, o consumidor-profissional provar em juízo a sua vulnerabilidade jurídica. E. por fim, a vulnerabilidade econômica, já está descartada de plano, por não se conceber que um profissional ou empresa possa ser vulnerável economicamente, algo que a nosso ver é extremamente discutível.

Um segundo conceito de consumidor (consumidor por equiparação) está no parágrafo único do art. $2^{\circ}$ : "Equipara-se a consumidor a coletividade de pessoas, ainda que indetermináveis, que haja intervindo nas relações de consumo" Vê-se,

\footnotetext{
+ WALD, Amold. O direito do consumidor e suas repercussões em relação às instituições financeiras. Revisla dos Tribunais, v. 666, p. 07-17, abr. 1991.

* LEÃES, Luiz Gastão Paes de Barros. op. cit, p. 17.

sh DONATO, Maria Antonieta Zanardo. op. cit, p. 88.
} 
portanto, a enorme tentativa do legislador consumerista em abranger o maior número possível de consumidores para, então, diminuir o que a doutrina chama de "litigiosidade contida"

Esta definição pretende dar maior efetividade ao sistema de defesa coletiva dos direitos dos consumidores instituídos pelo $\mathrm{CDC}$, rompendo com o individualismo marcante no Código de Processo Civil do século XIX.

Percebe-se que o CDC não fez qualquer diferença entre o consumidor individual e do coletivamente considerado. E até incluiu a coletividade no próprio art. $2^{\circ}$ da lei que trata do conceito padrão, ou seja, geral de consumidor.

Neste ponto, a doutrina divide-se, alguns, como Maria Antonieta Z. Donato $^{47}$ diz que deve ser feita uma restrição ao conceito de consumidor coletivo, no sentido de incluir tão somente aquelas pessoas que efetivamente participaram da relação de consumo na qualidade de adquirente ou usuário do produto ou serviço como destinatário final.

Um outro conceito de consumidor por equiparação são as "vitimas de acidente de consumo" ou "bystanders", mas aqui de maneira mais específica, no seu art. 17: "Para os efeitos desta Seção (da responsabilidade pelo fato do produto e do serviço), equiparam-se aos consumidores todas as vítimas do evento" (observação nossa)

Este conceito visa a proteger não-só aqueles que tenham, efetivamente, participado da relação de consumo, e que em conseqüência disto tenham a posse de algum produto ou que tenham efetivamente se beneficiado deste ou de algum serviço, mas, também, aquelas pessoas que sofreram algum dano decorrente da atividade profissional do fornecedor.

Esta figura jurídica de consumidor é denominada pela doutrina. fundamentada na terminologia norte americana, de "bystanders", que significa os "circunstantes" 48

Justifica-se esta inclusão, pois a norma consumerista objetiva reparar o dano não-só decorrente de uma compra e venda, por exemplo, mas todo e qualquer dano advindo de um ilícito decorrente da atividade profissional do fornecedor. Permitindo que terceiros sejam protegidos e amparados pela responsabilidade objetiva pelo fato do produto ou do serviço.

Em suma. o sistema de responsabilização do fornecedor adotado pelo código, foi o da Teoriu do Risco da Atividade, segundo esta teoria o fornecedor assume a

47 DONATO, Maria Antonieta Zanardo. op. cit., p. 187.

4. DALL'AGNOL JR.. Antônio Janyr. op. cit., p. 10. 
responsabilidade de eventuais danos causados em decorrência dos produtos e serviços colocados no mercado de consumo.

Em outras palavras, independe de culpa, basta que a vítima prove o dano sofrido e o nexo de causalidade entre a aquisição ou utilização do produto ou serviço e o prejuizo sofrido. Exemplo desta figura de consumidor foi o infeliz acidente no "Plaza Shopping de Osasco" na capital paulista, em que a sentença condenatória estendeu as indenizações por danos materiais e morais às pessoas que estavam nas instalações do shopping.

Por fim, tem-se outro conceito de consumidor por equiparação, aquelas pessoas "expostas às práticas comerciais", ou seja, o art. 29 do CDC traz uma definição de consumidor por ficção legal.

Nelson Nery Júnior ${ }^{49}$ posiciona-se no sentido de que mesmo sem adquirir produto ou utilizar-se de serviço, é consumidor mesmo aquelas pessoas que estiverem expostas às práticas comerciais.

Neste sentido, Dall'Agnol Jr., ${ }^{5 n}$ para quem a norma do art. 29 do CDC impõe que o consumidor seja visto abstratamente, ou seja, o que importa é a "simples exposição à prática" comercial, mesmo que não haja um consumidor em concreto que tenha adquirido ou utilizado o produto ou serviço.

Zanellato $^{\text {S1 }}$ adota uma posição finalista ao analisar este tipo de consumidor por equiparação, dizendo que o art. 29 do CDC deve ser interpretado em conjunto com o caput do art. $2^{\circ}$, justificando que tão somente o consumidor tem interesse em ser usuário ou adquirente de um serviço ou produto é que poderá valer-se da definição do art. 29 , mesmo se ainda não celebrou o contrato de aquisição do produto ou do serviço.

Donato $^{52}$ afirma que este conceito equiparado de consumidor atinge $o$ "ápice da extensão subjetiva", e por isso, difere-se das demais que visam a uma análise mais restrita da figura do consumidor, que nos parece a posição mais acertada.

\subsection{As instituições financeiras como fornecedoras}

A figura do fornecedor é definida no art. $3^{\circ}$ do CDC, que diz ser fornecedor para fins do referido diploma legal: "toda pessoa fisica ou jurídica, pública ou privada, nacional ou estrangeira, bem como os entes despersonalizados, que desenvolvem atividad's de produção, montagem, criação, construção, transformação,

\footnotetext{
49 NERY JÚNIOR, Nelson. Defesa do consumidor de crédito bancário cm juizo. Revista de Direito Privado, São Paulo, n. 05. p. 192-222, jan./mar. 2001.

so DAI.L'AGNOL JUNIOR, Antônio Janyr. op. cit., p. 12.

SI ZANELI.ATO, Marco Antònio. op. cit., p. 35.

52 DONATO, Maria Antonieta Zanardo. op. cit, p. 243.
} 
importação, exportação, distribuição ou comercialização e produtos ou prestação de serviços" Note-se que a definição pretendeu ser a mais ampla possível, e não se excluiu pessoa física, principalmente, os profissionais liberais que são especificamente abordados no $\S 4^{\circ}$ do art. 14 que trata da responsabilidade dos profissionais liberais.

Não foram excluídos, também, os entes públicos, como os da administração pública indireta (autarquias, fundações. etc.). Incluíram-se, também, os entes despersonalizados, como por exemplo, as sociedades de fato e quaisquer formas de cooperação ou atividade em comum. Importante ressaltar que não há distinção entre nacionais ou estrangeiros.

Disto, conclui-se que não importa a roupagem utilizada pelo fornecedor, basta que ele exerça uma atividade a título profissional atuando no mercado de consumo.

Cabe ressaltar que o CDC responsabiliza tanto o fornecedor imediato ou direto (comerciante ou ofertante do produto ou serviço), bem como o fornecedor mediato ou indireto (fabricante, produtor, construtor, importador, montador, criador. transformador, exportador, distribuidor, etc.). De forma que ao utilizar o termo fornecedor, tem-se em mente o gênero de que são espécies todos os que participam desde a fabricação até a distribuição do bem ao mercado.

Para caracterizar um fornecedor, é necessário que se identifique o caráter profissional de sua atividade. ${ }^{\varsigma 2}$ Georges Ripert ${ }^{\varsigma 4}$ identifica o jus utendi do fornecedor que fabrica os produtos; o jus fruendi, porque se apodera dos produtos, e tem, também, o jus abutendi porque os vende.

E conclui que os fornecedores têm enorme poder político porque detêm a propriedade dos bens de produção, podendo controlar e direcionar a produção de produtos e a prestação de serviços.

Em suma o conceito de fornecedor é amplo, e dá ênfase ao caráter da profissionalidade, mediante uma remuneração. que pode ser direta ou indireta. Feita esta breve introdução, as instituições financeiras são fornecedoras para efeitos da aplicação das normas do CDC.

Messineo $^{55}$ já definia Banco como entidade profissional, evidenciando assim a conotação de fornecedor ou prestador de serviços que o próprio Código de Defesa do Consumidor. em seu art. $3^{\circ}, \S 2^{\circ}$, diz expressamente que as atividades bancárias, financeiras e creditícias estão englobadas pelo referido estatuto legal.

33 DALL'AGNOL Il NIOR, Antōnio Janyr. up. cit. p. 09.

st RIPERT, Georges. op. cit., p. 379.

55 apud COVELLO, Sérgio Carlos. Contratos bancários. 4. ed. rev. é atual. São Paulo: Liv. e Ed. Universitária de Direito, 2001. p. 14. 
D'Angelo Mazzatine ${ }^{56}$ define Banco como "empresa intermediadora do crédito"

Seguindo esta linha de raciocínio, conclui Covello $^{57}$ que Banco pode ser definido como "empresa que tem por escopo principalmente a intermediação do crédito mediante operações típicas que envolvem aqueles que dão o dinheiro e aqueles que $o$ recebem"

O referido autor dá ênfase à profissionalidade que é característica marcante do Banco que é "empresa especializada no comércio do crédito e como tal aufere lucros das operações que realiza"

Portanto, parece-nos pacífico o entendimento de que as instituições financeiras são fornecedoras de produtos (dinheiro e crédito) e realizam suas atividades, com profissionalidade, mediante remuneração (pois aufere lucros).

No mesmo sentido Orlando Gomes ${ }^{5 \AA}$ ao definir contratos bancários utiliza a expressão "empresa autorizada a exercer atividades próprias dos Bancos" como individualização de um dos pólos dos contratos bancários, que deve ser sempre uma instituição financeira.

Nery $\mathrm{Jr}^{59}$ deixa consignado não restar dúvida quanto à natureza juridica dos Bancos como empresarial. Aliás, o próprio CCom. (hoje revogado), em seu artigo 119 definia a atividade dos Bancos como atos de mercancia ("São considerados banqueiros os comerciantes que têm por profissão habitual do seu comércio as operações chamadas de Banco").

Portanto estão perfeitamente de acordo com a definição do CDC, acima tratada. Além disso. o art. $2^{\circ}, \S 1^{\circ}$ da Lei das Sociedades Anônimas (Lei n. 6.404/76), determina que as instituições financeiras são comerciantes de produtos (crédito). pois exercem atividades de mercancia. São também prestadores de serviços, ex vi legis o $\$ 2^{\circ}$ do art. $3^{\circ}$ do CDC. ${ }^{60}$

s6 apud COVELlo, Sérgio Carlos. Contratos bancários. 4. ed. rev. e atual. São Paulo: I.iv. e Ed. Universitária de Direito. 2001. p. 15.

57 apud Id. Ibid., p. 15.

s8 GOMES, Orlando. Contratos. 18. ed. atual. Rio de Janeiro: Forense, 1999. p. 323.

59 NERY JÚNIOR, Nelson. Defesa do consumidor de crédito bancário em juizo. Revisıa de Direito Privado, São Paulo, n. 05, p. 192-222, jan./mar. 2001. Nesta mesma obra, p. 199: "Portanto, o Banco é sempre fornccedor." A pergunta que se deve fazer é se a outra parte é ou não consumidor (destinatário final dos produtos e serviços bancários. A resposta a esta pergunta deve-se atentar aos 4 conceitos de consumidor que o CDC proporciona, e que tratamos no item 3.1.1. Conceito juridico de consumidor.

on "Lei das S.A.: $\$ 1^{\circ}\left(\right.$ art. $\left.2^{\circ}\right)$ : Qualquer que seja o objeto, a companhia é mercantil e se rege pelas leis e usos do comércio." Neste sentido: NÉRY JÚNIOR, Nelson. Os principios gerais do Código Brasileiro de Defesa do Consumidor. Revista de Direito do Consumidor. São Paulo. n. 03. p. 44-77, set./dez. 1992. p. 54: "Em resumo. o Banco é sempre fomecedor: no entanto, nem sempre seus contratos são contratos de consumo. impendendo-se analisar se se encontra presente o elemento finalistico caracterizador das relaçöes de consumo (aquisição do produto ou utilização do serviço para destinação final do consumidor - art. $2^{\circ}$. caput)" 
Assim, os Bancos são fornecedores de produtos, quando contratam sobre o crédito (sendo esta a atividade negocial típica destes); mas também, podem ser prestadores de serviços, tais como aluguel de cofre, cobrança de tributos mesmo de indivíduos que não integram sua clientela (neste caso, o Banco desempenha o que se chama de função atípica). Todavia, em ambos os casos são passiveis de serem objetos de uma relação de consumo definida no art. $3^{\circ}$ do $C D C$.

No mesmo sentido, Newton De Lucca ${ }^{61}$ afirma que os Bancos sempre serão comerciantes (empresários, propriamente dito). A atividade profissional dos Bancos é refletida na adoção de uma forma padrão na prestação de serviçus e contratação, que são feitos geralmente através de "contratos-formulários", que contêm apenas alguns espaços em branco para que o cliente preencha com seus dados pessoais.

Hoje os Bancos, em sua fase capitalista em uma sociedade "bancarizada", tornaram-se elemento indispensável à sobrevivência das empresas, bem como dos indivíduos (via de regra, consumidores).

Foi a partir do século XVIII que os Bancos passaram a ser fundamental para a economia moderna em escala mundial. No Brasil, já em 1849 havia uma Resolução (n. 172, de 03 de janeiro) baixada pelo Conselho de Estado e que sujeitava o funcionamento dos Bancos à autorização do Estado, devido à relevância social destas instituições.

O próprio Decreto n. 737 , de 25 de novembro de 1850 , incluiu as operações de Banco, de câmbio e de corretagem entre os atos de comércio. Surgindo após este Decreto inúmeros outros e leis esparsas que regulam a atividade bancária.

Hodiernamente, as instituições financeiras são basicamente reguladas pela Lei n. 4.595, de 31 de dezembro de 1964, conhecida como Lei de Reforma Bancária, que reorganizou o sistema.

Conclui-se que as instituições financerias, bancárias, creditícias e securitárias são tidas como fornecedores de produtos e serviços, mesmo nas hipóteses de se utilizar formas "aparentemente" gratuitas de captação de clientela para seus serviços e produtos remunerados, tratando-se do que chamamos de remuneração indireta, isto é, um benefício econômico auferido pelo fornecedor decorrente do produto oferecido ou serviço prestado.

6 DE LUCCA, Newton. A aplicação do Código de Defesa do Consumidor à atividade bancária. Revista de Direito do Consumidor, São Paulo, v. 27, p. 78-87, jul./set. 1996. p. 79. No mesmo sentido: EFING. Antònio Carlos. Conrralos e procedimentos bancários à luz do Código de Defesa do Consumidor. 1. ed. 3. tir. São Paulo: Revista dos Tribunais, 2000. p. 14. 
E como bem nos aponta Efing:"62 "Aliás, em momentos de indice inflacionário baixo, todas as instituições financeiras apelam para a cobrança de taxas em decorrência de qualquer serviço prestado ao consumidor" configurando a remuneração direta dos serviços e contratos bancários. Todavia, em periodos de altos índices inflacionários, ou quando não se cobram taxas pelos serviços e contratos bancários, os juros e ofloat caracterizam a remuneração indireta.

\subsection{Os produtos e serviços à luz do CDC}

Os produtos e serviços têm sua qualidade e preço estabelecido pelos agentes de mercado (fornecedores) cabendo aos consumidores aceitá-los se quiser usufruir destes. Na realidade, os fornecedores não permitem uma discussão da qualidade e do preço dos produtos e serviços prestados.

O poderio dos fornecedores não pára por aí, eles também têm influência na formação da legislação aplicável ${ }^{63}$ à sua atividade, como se pode notar pela ADIn $n$. 2.591, ainda em tramitação no Supremo Tribunal Federal, c que visa a anular a aplicação do CDC a suas atividades como já visto, representando a força dos lobbies empresariais. E a recente emenda constitucional n. 40, de 29 de maio de 2003 que alterou o inciso $\mathrm{V}$ do art. 163 da CF/88 e o art. 192, revogando inclusive a limitação dos juros em $12 \%$ (doze por cento) ao ano.

Os elementos objetivos da relação de consumo com as instituições financeiras são, basicamente, o dinheiro e o crédito. Crédito vem do latim creditum, significando confiança, empréstimo, divida. Num sentido jurídico, Covello ${ }^{64}$ o define como "o direito que tem o titular a uma prestação de natureza patrimonial". Apontando como características do crédito: a confiança: entendida em seu duplo aspecto, a confiança do cliente no estabelecimento bancário e a deste no cliente; o prazo: a concessão do crédito é diferida no tempo; o interesse ou juro: que podem ser retributivos (cuja finalidade é remunerar o capital cedido) ou moratórios (visam a compensar o atraso do pagamento, portanto é, também, uma forma de punição imposta ao devedor que descumpre o contrato); e o risco: que por sua vez é inerente ao crédito.

O crédito privado pode ser marítimo, agrícola, industrial, comercial ou individual, este último é o que interessa para esta pesquisa, pois não raro representa um crédito de consumo, como bem nos demonstra Covello:"6s "Quem solicita este tipo de

\footnotetext{
62 EFING, Antônio Carlos. op. cit., p. 64.

63 ALMEIDA. Carlos F. de. op. cit., p. 18.

64 COVELLO, Sérgio Carlos. op. cit., p. 48

6s Id. Ibid., p. 51.
} 
crédito ao Banco o faz porque precisa comprar objetos de sua necessidade. É o crédito típico dos financiamentos para aquisição de hens ou serviços, que, hoje em dia, são de uma constância extraordinária"

O crédito nada mais é que um bem imaterial, e por isso mesmo é passível de ser enquadrado na definição de produtos do $\S 1^{\circ}$, art. $3^{\circ}$ do CDC, e também poderá ser enquadrado na definição de serviços do $\S 2^{\circ}$ do mesmo artigo.

O próprio art. 86 do $\mathrm{CC} / 02$ insere dentro da categoria de bens consumiveis: os materialmente consumiveis, que são destruídos pela utilização, como por exemplo, comida; - os juridicamente consumíveis, aqueles que se destinam à alienação, como por exemplo o dinheiro. ${ }^{66}$

O CDC não faz distinção entre estas duas grandes categorias, portanto, ambas estão inclusas no conceito de produto. Se o CDC fizesse diferença, as roupas, sapatos, livros fornecidos que são tidos como bens juridicamente consumíveis não poderiam ser regulados pelo CDC, o que confrontaria com o espírito da legislação em análise, que visa a tutelar justamente a relação de consumo cujos objetos são justamente os supra citados, além de outros.

Arnold Wald, ${ }^{67}$ ao contrário da doutrina dominante, afirma que o CDC aplica-se tão-somente aos bens materialmente consumíveis, excluindo então os juridicamente consumíveis, que são destinados à alienação e, por isso, afirma o autor que não poderiam ser utilizados como destinatários finais. Desta forma, este autor afirma que os empréstimos, descontos, aberturas de créditos e as outras operações bancárias que envolvem a entrega (obrigações de dar) imediata, diferida ou condicional de um crédito (dinheiro) não podem ser enquadradas como produtos para fins de aplicação do CDC. Entretanto, o autor diz que em se tratando de obrigações de fazer, isto é, os serviços prestados pelos Bancos, só estes podem ser enquadrados em uma relação de consumo para aplicar os dispositivos do CDC.

Em suma. os objetos de uma relação de consumo são os chamados bens de consumo, ou seja. aqueles que se destinam "à satisfação de uma necessidade imediata, a qual, via de regra, exaure o próprio bem, eliminando-lhe a substância" Distinguindo-se dos bens de capital ou de insumo que voltam para melhorar os meios de produção. ${ }^{68}$

66 NERY JÍNIUR, Nelson. Defesa do consumidor de crédito bancário em juizo. Revista de Direito Privado, São Paulo, n. 05, p. 192-222, jan./mar. 2001.

67 WALD, Arnold. O dircito do consumidor c suas repercussỏes em relação às instituições financeiras. Revista dos Tribunais, v. 666, p. 07-17. abr. 1991.

68 Sobre isto conferir: PASQUALOTTO, Adalberto. Conceitos fundamentais do Código de Defesa do Consumidor. Revisı dos Tribunais, São Paulo, n. 660, p. 48-53, abr. 1991 
Newton De Lucca ${ }^{69}$ cita um exemplo para esclarecer a aplicação do CDC aos Bancos. Afirma que há várias maneiras de se conceder crédito aos consumidores. Uma delas é quando o consumidor vai diretamente à loja que the vende o produto em prestações (sem a intermediação de um Banco) neste caso o CDC é aplicado sem discussão. Mas uma outra forma de conceder crédito ao consumidor é não diretamente pelo fornecedor, e sim por um Banco. Forma-se então um contrato de mútuo entre o consumidor e o Banco e não poderia ser diferente da primeira hipótese em que o CDC. é aplicado. Neste último caso, forma-se duas relações de consumo: 1. consumidor e formecedor do bem; e, 2. consumidor e Bancos.

É de se concluir que o elemento objetivo da relação quando for um crédito dado pelas instituições financeiras deve estar intimamente ligado com o mercado de consumo, ou seja, à venda em massa de bens ou prestação de serviços aos consumidores (crédito ao consumo - consumer credit - crédit à la consommation).

Em outras palavras, a operação bancária deve ter como objetivo específico a aquisição ou utilização de bens ou serviços pelo consumidor como destinatário final (para compra pessoal, bem como para suprir as necessidades familiares e domésticas). ${ }^{70}$ E, também, nas hipóteses em que as instituições financeiras figuram como prestadoras de serviços, como na cobrança de títulos, aluguel de cofres de segurança, etc.

\section{Teoria Maximilista e Finalista}

A análise do âmbito de aplicação do CDC deve ser feita sob dois enfoques: o primeiro enfoque dado pelos Finalistas, com origem na doutrina francesa, a aplicação das normas do CDC são destinadas tão apenas àqueles que adquirem ou utilizam um produto como destinatários finais, ou seja, para uso próprio ou de sua família (excluindo tão somente o uso profissional); - o segundo, trazido pelos doutrinadores Maximalistas, estende a aplicação das normas do CDC a todos os indivíduos que retiram o produto do mercado de consumo, sendo, portanto, o destinatário fático deste bem, pouco importando a utilidade do mesmo (profissional ou-não), basta que este indivíduo não repasse o bem para o mercado de consumo.

Newton De Lucca ${ }^{71}$ nos explica estas duas correntes utilizando o contrato de mútuo entre um empresário e uma instituição financeira. Neste contrato deve ser analisado se o empresário estaria utilizando o dinheiro emprestado pelos Bancos como

\footnotetext{
6) DE LUCCA, Newton. op. cit., p. 83.

70 LEÃES, Luiz Gastão Paes de Barros. op. cit., p. 22.

7 DE LUCCA, Newton. op. cit., p. 84.
} 
destinatário final, segundo a Teoria Finalista, que para este autor é a mais acertada, pois requer uma análise do aspecto teleológico da proteção do consumidor pelo CDC.

Diversamente a Teoria Maximilista, ${ }^{72}$ defende que 0 conceito de consumidor deve ser entendido o mais amplamente possível. Para aqueles que defendem tal posicionamento, a justificativa é que o CDC visa à imposição de regras morais às relações de consumo, e por isso, pretendeu tutelar todos os destinatários finais, ainda que tão somente "destinatários fáticos", sendo ou-não hipossuficientes. ${ }^{73}$

Edilson Pereira Nobre $\mathrm{Jr}^{74}$ acrescenta outra diferença entre estas duas teorias, dizendo que a corrente finalista ou teleológica analisa objetivamente a destinação do produto ou serviço. Desta forma, a pessoa jurídica só poderá ser enquadrada na definição de consumidor quando não tiver intuito lucrativo, ou seja, tão somente as "associações e entidades de beneficência"

Para esta corrente a tutela do consumidor só será legítima tendo em vista a vulnerabilidade da parte consumidora (art. $4^{\circ} \mathrm{I}$ ), ou seja, o CDC objetiva reequilibrar a relação entre consumidores e fornecedores. Por isso, só caberia esta proteção para o indivíduo que adquira produtos ou utilizem serviços para uso próprio ou de sua familia, que são tidas como vulneráveis no mercado de consumo. Deixando à margem desta proteção o "consumidor-profissional" e a pessoa jurídica.

Hoje este entendimento sofreu variações, pois os finalistas passaram a admitir a aplicação das normas do $\mathrm{CDC}$ às pequenas empresas desde que estas comprovem em juízo a sua situação de vulnerabilidade. ${ }^{75}$

No lado oposto, a corrente maximilista defende que a expressão "destinatário final" deve ser entendida em seu aspecto fático, ou seja, basta a retirada do produto ou serviço do mercado de consumo, "nada impedindo a sua utilização como fonte de receita pelo adquirente" Percebe-se que a interpretação da figura do consumidor deve ser a mais ampla possível.

Assim, defendem os maximalistas que as normas do CDC visam a regulamentar o mercado de consumo, de maneira que a proteção do referido Estatuto será lícita se tratar de uma atividade de consumo lato sensu. ou seja, basta a destinação final fática, que é a retirada do produto ou serviço, não importando se serão utilizados

12 neste sentido: MARJNS, James. Proteção contratual do CDC a contratos interempresariais, inclusive bancários. Revista de Direito do Consumidor, São Paulo, v. 18, p. 94-104, abr./jun. de 1996. p. 104.

7 EFING, Antônio Carlos. Contratos e procedimentos bancários à luz do Código de Defesa do Consumidor. 1. ed. 3. tir. São Paulo: Revista dos Tribunais, 2000. p. 45-46.

is NOBRE JR., Edilson Pereira. A proteção contratual no código do consumidor e o âmbito de sua aplicação. Revista de Direilo do Consumidor, São Paulo, n. 27, p. 57-77. jul./set. 1996.

7 DONATO, Maria Antonieta Zanardo. Proteção ao consumidor: conceito e extensão. São Paulo: Revista dos Tribunais, 1993. p. 92. 
para suprir necessidades pessoais e familiares do consumidor ou se este as utilizará com uma finalidade profissional. O que não pode ocorrer é que esta atividade profissional repasse o bem adquirido pelo profissional da mesma forma, sem nenhuma alteração, pois neste caso a atividade é clara de repasse, não se aplicando as regras do CDC.

Tem surgido, também, posições intermediárias, como o caso de Edilson Pereira Nobre Jr., ${ }^{76}$ que é adepto à teoria finalista, porém reconhece que em certas situações, poderá o adquirente profissional provar sua vulnerabilidade, e assim poderá invocar as normas do CDC em seu favor. Esta nos parece a posição mais acertada. mesmo porque após o $\mathrm{CC} / 02$, cujas diretrizes são a sociabilidade, eticidade e operabilidade, o Direito Contratual revestiu-se com novos princípios e regras de condutas muito semelhantes às do $\mathrm{CDC}$, possibilitando a teoria do "Diálogo das Fontes"?" "A convergência de principios é vista hoje como um fato bastante positivo para a cohabitação (ou diálogo) das leis novas e antigas no mesmo sistema juridico. É o que ocorrerá com o CDC e o CC/02"

Sendo assim, ao nosso ver, a distinção entre maximalistas e finalistas tende a diminuir ou ter menos importância, já que com as novas regras e princípios do CC/02, como a imposição do princípio da probidade e da boa-fé objetiva (art. 422 do CC/02), função social do contrato (art. 421 do $C(/ 02)$ ), responsabilidade objetiva fundamentada na Teoria do Risco da Atividade (par. ún. do art. 927 do CC/02), dentre outras, a tutela jurídica contratual do $\mathrm{CC} / 02$ e a do $\mathrm{CDC}$ está bem próxima. Diferentemente quando o CC/16 ainda estava em vigor, predominado pelos ideais do liberalismo econômico e vonluntarismo jurídico, havia um abismo entre as regras de conduta e os princípios do Direito Contratual Privado e das normas do CDC.

Contudo. o CDC é norma especial, portanto, é a lei básica aplicada às relações de consumo, ou seja, sempre que o fornecedor atue com profissionalidade, e o consumidor utilize os produtos e serviços como destinatário final, excluindo o uso profissional.

${ }_{76}$ NOBRE JR, Edilson Pereira. A proteção contratual no código du consumidor e o âmbito de sua aplicação. Revista de Direilo do Consumidor, São Paulo, n. 27, p. 57-77. jul./set. 1996. No mesmo suntido: DONATO, Maria Antonieta Zanardu. op. cit., p. 108.

17 MARQUES, Cláudia Lima; BENJAMIN. Antônio Herman V.: MIRAGEM, Bruno. Comentários ao Código de Defesa do Consumidor: arts. $1^{\circ}$ a 74 . Aspectus Matcriais. São Paulo: Revista dos Tribunais. 2003. p. 24-52. 
6. Alguns serviços e produtos bancários que comprovam a existência de relação de consumo

Nesta parte deste breve estudo, pretende-se demonstrar a existência de relação de consumo com os Bancos, desde que o indivíduo que utiliza os serviços ou produtos bancários o faça como destinatário final, verificando, no caso concreto a vulnerabilidade e a hipossuficiência deste que o faz merecedor da proteção do $\mathrm{CDC}^{78}$ com o objetivo de reequilibrar esta relação jurídica. Esta análise será feita tendo-se em vista as peculiaridades das atividades bancárias, vez que o objeto das operações bancárias é o dinheiro e o crédito; a homogeneidade, que reflete a contratação em massa para maior obtenção de lucros; a complexidade, devido à constante evolução técnica e comercial; a profissionalidade, que é a intermediação do crédito; e a comercialidade, pois se consideram as atividades bancárias como atos de comércio. ${ }^{79}$

Os produtos bancários podem ser resumidos na expressão "crédito" já que este, na definição de Almeida, ${ }^{80}$ é uma operação mediante a qual uma parte cede a outra um bem tendo em vista uma contra-prestação futura. Sendo que para se afirmar que um crédito é ou-não de consumo, deve-se analisar a finalidade do mesmo, isto é, se serão diretamente utilizados, será relação de consumo; caso contrário, será ora uma relação entre particulares (de natureza civil) ora uma relação entre empresas (de natureza empresarial).

Os contratos bancários são múltiplos, pois oferecem diversos serviços, além de concessão de crédito mercantil, os Bancos administram. remuneram o capital e garantem o rendimento. Dai a subdivisão das operações bancárias em principais e acessórias.

Orlando Gomes ${ }^{81}$ subdivide as operações bancárias em principais ou típicas, que são aquelas mais utilizadas na prática das instituições financeiras. Em oposição, o Autor cita as operações acessórias ou atipicas, que seriam aquelas que escapam à principal função econômica dos Bancos, note-se que não significa dependência de outra operação.

78 "CONTRATOS BANCÁRIOS. Relação de consumo. Aplicabilidade do Código de Defesa do Consumidor. Inversão do ônus da prova. Ementa: Os contratos bancários se submetem às normas do Código de Defesa do Consumidor por expressa disposição nele contida (art. $3^{\circ}, \S 2^{\circ}$, do $\mathrm{CDC}$ ). assim, é possivel ao magistrado, vislumbrando situação de hipossuficiência do agravado impor o ônus da inversão da prova." Agln n. 163.324-7 - 6 Câm. Civ. - TAPR - j. 12.03.2001 - rela. Juiza Maria José l'eixeira. Revisıa dos Tribunais, p. 373-375.

79 COVELlO, Sérgio Carlos. Contratos bancários. 4. ed. rev. e atual. São Paulo: Liv. e Ed. Lniversitária de Direito, 2001 . p. 37.

80 ALMEIDA, Carlos Ferreira de Almeida. Os direitos dos consumidores. 1. ed. Coimbra: Almedina. 1982. p. 142.

8) GOMES, Orlando. Contratos. 18. ed. Rio de Janeiro: Forense, 1999. p. 323. 
Nesta classificação, as operações bancárias, tidas como fundamentais ou típicas, podem ser passivas, quando o Banco é devedor, ou seja, utiliza o capital de seus clientes (exemplos: depósitos, contas correntes. redescontos); e podem ser ativas, quando o Banco é credor, e neste caso concede crédito a seus clientes (exemplos: conta corrente, empréstimos, financiamentos, abertura de crédito, descontos. créditos documentários, antecipações, dentre outras).

Dentre estas atividades de crédito, Almeida ${ }^{82}$ as classifica como: 1. de crédito bancário pessoal: 2 . venda a prestações; 3 . prestação de serviços com pagamento diferido; 4. cartão de crédito;

Note que algumas operações bancárias, como os depósitos ou contas correntes, ora serão passivas ora ativas. Serão passivas quando o cliente entrega em depósito ou conta corrente quantia que fica a disposição dos Bancos. Serão ativas quando as instituições financeiras concederem crédito como nas antecipações de depósitos ou de limite especial nas contas correntes.

Operações acessórias ou atípicas podem ser traduzidas em prestações de serviços do Banco a seus clientes com o fito de atrair maior clientela. Estes serviços são altamente especializados, ou seja, prestados como maior segurança do que se fosse prestado por um particular. Exemplos: custódia de valor, caixa de segurança, cobrança de títulos, etc.

As operações bancárias nada mais são que contratos bancários, mas a primeira expressão é mais utilizada, pois reflete o dinamismo característico destes contratos.

As operações bancárias são em regra onerosas, contrariando a característica do $\mathrm{CC} / 02$, que diz scr gratuito o contrato de mútuo, ressalvada a hipótese do mútuo feneratício (que tenha finalidade econômica) do art. 591do CC/02, em que se presumem devidos os juros.

Diante disto, fica fácil comprovar a remuneração direta ou indireta das instituições financeiras, isto porque os juros segundo as palavras de Arnaldo Rizzardo ${ }^{83}$ são: "proveito tirado do capital emprestado, ou a renda do dinheiro, como o aluguel é o preço correspondente ao uso da coisa locada no contrato de locação"

Quanto a esta questão não há dúvida de que os juros são meio utilizados pelos Bancos para arrecadar recursos através de suas operações. Tanto é assim que o Jornal Folha de S. Paulo ${ }^{84}$ traz uma matéria neste sentido, e afirma que no primeiro semestre de 2002, os Bancos lucraram R\$ 9,7 bilhões. Diante de tal fato não se pode

82 ALMEIDA, Carlos Ferreira de Almeida. op. cit., p. 143.

83 RIZZARDO. Amaldo. Contratos de crédito bancário. 5. ed. rev., atual. e ampl. Sào Paulo: Revista dos Tribunais, 2000. p. 365. 
negar que os juros são uma forma de remuneração indireta, pois através deles as instituições financeiras obtêm enormes lucros em sua atividade.

Uma característica bem presente é a contratação em massa, através de formulários com cláusulas gerais e uniformes para todos, os chamados Contratos de Adesão, aumentando o grau de vulnerabilidade e hipossuficiência dos que necessitam destes contratos. A estes restam apenas uma alternativa: aceitar em bloco as condições impostas, vez que sua necessidade lhe impõe tal comportamento. Mesmo porque há uma uniformidade nestes contratos adotada por todos os Bancos, pela própria imposição do Banco Central, tendo um papel decisivo na proteção dos aderentes.

A vulnerabilidade e hipossuficiência dos consumidores diante dos Bancos são ressaltadas pela doutrina:

Ora, na contratação bancária. o Banco é sempre o mais forle. já por sua solidez econômica, já pela própria natureza da atividade que exerce. Deixar o Bunco ugir livremente, como se pretendeu sob o liberulismo econômico, é o mesmo que permitir a exploração do mais fraco. A simples leitura dos formulários de contrato bancário revela a existência de condições leoninas acobertadas pelo manto da legalidade, como a conhecida cláusula de outorga de procuração do cliente ao próprio Banco para que este possa emitir cambial a fim de cobrar a divida de maneira mais rápida e eficaz mediante execução. ${ }^{\$ 4}$

Disto conclui-se a função social que as instituições financeiras devem cumprir na sociedade, cabendo ao Estado fiscalizá-la. Passaremos então à análise em particular dos contratos mais comuns entre as instituições financeiras e o consumidor.

\subsection{Contrato de abertura de conta corrente}

O contrato de conta corrente, também, denominado de, "conta corrente imprópria". "conta de gestão" ou "conta corrente de correspondência" é a figura contratual mais típica realizadas entre os Bancos e seus clientes (os correntistas).

${ }^{34}$ São Paulo, Quinta-feira, 28 de novembro de 2002. Caderno FOLHA DINHEIRO, página BI - B4. TAXA DE JURO SOBE 'TREMENDAMENTE', DIZ BC.

8. COVELLO. Sérgio Carlos. Contratos bancários. 4. ed. rev. e atual. São Paulo: Liv. e Ed. Universitária de Direito, 2001. (grifo nosso) 
Segundo a definição de Covello "é o contrato em virtude do qual o Banco se obriga a receber os valores que lhe são remetidos pelo cliente (correntista) ou por terceiros, bem como a cumprir as ordens de pagamento do cliente até o limite de dinheiro nela depositado ou do crédito que se haja estipulado"

Seria um contrato que possibilita constantes alterações entre o débito e o crédito do cliente, mediante compensação de débitos contrapostos. ${ }^{87}$ Importa em uma concessão recíproca de crédito entre Banco e cliente. Trata-se de uma operação típica dos Bancos, que ora será passiva (quando o saldo do cliente for positivo), ora será ativa (quando este saldo for negativo).

Neste contrato o Banco assume a posição de devedor, ou seja, é obrigado a realizar diversos serviços por conta do cliente, dentre os quais: pagamento dos cheques emitidos, bem como outros pagamentos (água, luz, telefone. e outras faturas). Portanto através do contrato de conta corrente, o Banco presta o que se chama de serviços de caixa. E assim, administra os ingressos (na sua maioria depósitos) e egressos (saques. pagamentos de contas) da conta de seu correntista. em outra palavras. é uma administração contábil.

Diante disto tudo. é cediço que esta figura contratual é indispensável para a subsistência na moderna sociedade "bancarizada"

Estes contratos são extremamente vantajosos para os Bancos, pois grande parte de seu lucro origina-se dos valores que estão disponiveis nas contas correntes ("float" - retenção de valores). O que leva ao enquadramento da remuneração indireta para fins de aplicação das normas elencadas no CDC. Mas podem também cobrar uma comissão de abertura da conta corrente sendo então uma remuneração direta.

Tendo em vista a onerosidade do contrato de conta corrente é perfeitamente enquadrado na definição de serviços do art. $3, \S 2^{\circ}$ do C.DC. basta que o cliente bancário seja efetivamente o destinatário final dos serviços de caixa prestados pelo Banco para configurar uma relação de consumo.

Uma das obrigações fundamentais dos Bancos nestes contratos é o dever de registrar de maneira contábil todos os ingressos e cgressos de fundos movimentados

86 COVELLO, Sérgio (arlos. op. cit., p. 98. Ressaltando o caráter relacional deste contrato, define-o MARQUES. Cláudia Lima. Contratos no Código de Defesa do Consumidor: o novo regime das relações contratuais. 4. ed. rev. atual. e ampl. São Paulo: Revista dos Tribunais. 2002. p. 447-448: "Caracteriza-se, pois. como uma relação múltipla e complexa de serviços. com um depósito básico. um plexo de serviços de escrituração e caixa especifícos e um objetivo claro: de possibilitar a inșurção da pessoa-depositante nu mundo financeiro e bancário brasileiro atual."

${ }^{87}$ GOMES, Orlando. Contrutos. 18. ed. atual. Rio de Janeiro: Forense. 1999. p. 332. 
pelo cliente, segundo afirmação de Covello ${ }^{88}$ Em decorrência desta obrigação fica claro o dever de informação dos Bancos a seus clientes. Para comprovar:

Consumidor - Ação revisional de contrato bancário - Ônus da prova imposto à instituição financeira - Admissibilidade - Inteligência do art. $6^{\circ}$, VIII, da Lei n. 8.078/90. Ementa da Redação: $\mathrm{Na}$ ação revisional de cuntrato bancário a instituição financeira pude ser obrigada a juntar documentos demonstrativos da evolução dos débitos e créditos se houver dificuldade do cliente em fazê-lo, em face do princípio da inversão do ônus da prova consagrado no art. $6^{\circ}$, VIII, da Lei n. 8.078/90. ${ }^{89}$

Sendo enquadrado como uma relação de consumo. o Banco dependerá de expressa autorização do seu cliente para lançar débitos em sua conta corrente (inciso VI do art. 39 do $\mathrm{CDC}$ ); deverá observar, dentre outros, o art. 42 do $\mathrm{CDC}$, que veda a utilizaçãu de meios vexatórios para cobrar uma dívida do consumidor: além disso, se lançar algum débito indevido. o consumidor terá o direito da repetição do indébito em dobro segundo o parágrafo único do mesmo artigo.

\subsection{Contrato de poupança}

Os contratos de poupança nada mais são que depósitos bancários, cuja finalidade é a capitalização privada de recursos, e por isso, gozam de incentivos fiscais. Decidimos estudar este contrato a parte devido a grande polêmica que gira em torno dele no que se refere à aplicação ou não dos dispositivos do CDC.

Os contratos de poupança são, geralmente, celebrados pelas pessoas menos favorecidas na sociedade, que vêem nestes contratos uma saída segura e barata para poupar suas economias, que são, via de regra, destinada ao consumo, isto é, à aquisição de produtos e serviços para o seu consumo e sua família.

${ }^{88}$ COVELlo, Sérgio Carlos. op. cit., p. 114.

89 Revista dos Tribunais, n. 758, dezembro de 1998, p.343-345. No mesmo sentido: “"CONTRATO DE ABERTURA DE CRÉDITO EM CONTA CORRENTE - Execução por título extrajudicial Inadmissibilidade - Instrumento acompanhado de extratos da conta - Irrelevância - Descabimento da instituição de crédito criar seus próprios títulos. CODDIGO DE DEFESA DO CONSUMIDOR - Contratos Bancário - Incidência de suas normas - Interpretação dos arts. $2^{\circ}$ e $3^{\circ}, \S 1^{\circ}$, do $\mathrm{CDC}$. Ementa da Redação: Incidem as normas do $C D C$ em relação aos contratos bancários, pois, se o produto é todo bem juridico. não há negar-se que o crédito ć um bem jurídico que é fornecido pelo Banco (fornecedor) ao tomador do crídito (consumidor), como destinatário final (do crédito), diante da interpretação dos arts. $2^{\circ}$ e $3^{\circ}, \S 1^{\circ}$ do próprı código." (Ap. 196.099.337 - 4a Câm. - j. 22.08.1996 - rel. Juiz Henrique Osı aldo Poeta Roenick.) Revista dus Tribumais, n. 734, p. 488-490, dez. 1996. 
Devido a este fato social a vulnerabilidade destes contratantes face às instituições financeiras é muito acentuada, o que demanda do Estado uma intervenção no sentido de tutelar o hipossuficiente. ${ }^{90}$

Sendo um depósito bancário, a remuneração indireta já foi demonstrada no item anterior, mediante a retenção destas quantias ("float").

Há várias modalidades de poupança, a saber: poupança livre, poupança programada, poupunça de rendimentos crescentes, poupança vinculada, poupança pecúlio e poupança rural.

Geralmente este investimento é realizado tendo em vista um ato de consumo futuro. Como no caso de um indivíduo que poupa para depois comprar um carro ou sua casa própria. Portanto presente esta figura, nada impede que este contrato seja enquadrado na definição de serviços e produtos do CDC. Neste sentido vem decidindo o Superior Tribunal de Justiça:

Processo Civil - Ação civil pública- Legitimidade ad
causam - Depósito em caderneta de poupança - Relação de
consumo. A caderneta de poupança é um produto oferecido
pelas instituições financeiras, cada qual dotando-o de
caracteristicas próprias, v.g. restituição da CPMF.
descontos nas tarifas dos serviços bancários. juros
privilegiados no cheque especial, sorteio de prêmios etc.;
tratando-se de relação protegida pelo Código de Defesa do
Consumidor [...]. ${ }^{91}$

Entretanto, parte isolada da doutrina ${ }^{92}$ sustenta a posição de que os dispositivos do CDC não se aplica às operações de poupança, pois estas não podem ser consideradas como relação de consumo já que thes faltam o elemento finalístico da destinação final.

Todavia a doutrina e jurisprudência majoritária9; entendem, no sentido contrário, que estes contratos são passíveis de ser de consumo, se o cliente (titular da poupança) é o destinatário final. A remuneração indireta é indiscutivel, pois as poupanças representam grande parte na captação de recursos pelas instituições financeiras.

9 MARQUES, Cláudia Lima. Contratos no Código de Defesa do Consumidor: o novo regime das relaçōes contratuais. 4. ed. rev. atual. e ampl. São Paulo: Revista dos Tribunais, 2002. p. 432

${ }^{9}$ SUPERIOR TRIBUNAL DE JUSTIÇA. REsp 138540/SP, 3a Turma. Rel. Min. Waldemar Zveiter. j. 29.03.2001.

92 WALD, Arnold. O direito do consumidor e suas repercussōes em relação às instituições financeiras. Revista dos Tribunais, v. 666, p. 07-17, abril 1991.

93 MARQUES, Cláudia Lima. Contratos no Código de Defesa do Consumidor: o novo regime das relaçōes contratuais. 4. ed. rev. atual. e ampl. Săo Paulo: Revista dos Tribunais, 2002. p. 453; EFING, Antônio Carlos. op. cit., p. 168. SUPERIOR TRIBUNAL DE JUSTIÇA. REsp n 170078/SP. $3^{a}$ Turma, Rel. Min. Carlos Alberto Menezes Direito, j. 03.04.2001“. 
Conclui-se que as cadernetas de poupança são relações de consumo quando a parte contratante com o Banco for um consumidor (vulnerável e hipossuficiente), sendo perfeitamente aplicáveis as normas do CDC.

\subsection{Caixas de segurança ou cofres individuais}

Também conhecido como contrato de cofres-fortes, cofres de aluguel ou caixas-forte, podendo ser definido como o contrato por meio do qual o Banco oferece a seu cliente determinado compartimento vazio na caixa-forte do Banco para que o cliente guarde seus pertences de valor (geralmente dinheiro, objetos e documentos), mediante remuneração pecuniária avençada no contrato. ${ }^{94}$

É uma operação acessória dos Bancos, pois esta não é sua principal função econômica.

A confiança neste sistema deve-se ao fato de que tais cofres são munidos de mecanismos de proteção de alta tecnologia. São construídos em blocos metálicos ou de cimento armado, não sendo possível arrombamentos e até mesmo são imunes a incêndios ou inundações. Ademais, há um rigoroso sistema de vigilância destes cofres.

Sendo por isso um serviço altamente qualificado e prestado só por instituições financeiras de alto padrão.

A natureza jurídica destes contratos não é pacifica, predomina o entendimento de ser um contrato misto, pois coexistem elementos dos contratos de locação, de prestação de serviços, e de depósito. ${ }^{95}$

Orlando Gomes ${ }^{96}$ defende a tese de ser um contrato atípico devido à dificuldade de enquadrá-lo nas figuras contratuais existentes, como o caso da locação, do depósito e da prestação de serviços, contendo elementos essenciais de todos estes contratos. Sendo que guarda maior proximidade com o contrato de depósito, pois a causa é, também, a guarda de valores.

A vantagem do cliente é a guarda altamente especializada de bens muito valiosos (como documentos, títulos-valores, jóias e até mesmo uma grande quantia em dinheiro).

Em contrapartida, as vantagens dos Bancos são: 1. cobrança de uma taxa para manutenção do cofre paga pelo cliente (remuneração direta do serviço); e, 2. atrai clientes, quanto a isto é bem comum que os Bancos condicionem a utilização de tal

COVELLO, Sérgio Carlos. op. cil., p. 297.

Id. Ibid., p. 305.

GOMES, Orlando. op. cit., p. 337. 
serviço á abertura de conta corrente com alto valor no saldo; prática, aliás, proibida pelo CDC (venda casada - art. 39, inciso I).

Estes contratos são sempre "formulários-tipos", contratos de adesão, uma vez que é praticamente impossivel que o cliente altere as normas internas referentes a este serviço já que são elaboradas para maior segurança.

As principais obrigações assumidas pelos Bancos são: - permitir o uso do cofre em perfeita condição mediante a entrega da chave ao cliente; - assegurar ao usuário a exclusividade do acesso ao cofre; - obrigação de custódia: conservação e defesa das caixas-fortes;

Do lado oposto da relação, as obrigações do usuário são: - pagamento da remuneração avençada: usar cofre de acordo com as normas internas do Banco; apresentar o cartão de identificação ao utilizar o cofre; devolver as chaves ao fim do contrato.

A responsabilidade dos Bancos é objetiva consoante arts. 12 e seguintes do CDC, uma vez já pacificado o entendimento em ser esta uma relação de consumo. Todavia a responsabilidade dos Bancos restringe-se à integridade dos objetos guardados e inviolabilidade do cofre. devendo permanecer sigiloso até para o Banco. Este não é responsabilizado pelo conteúdo do cofre, mesmo porque não pode fiscalizá-los. ${ }^{97}$ É o que se percebe pela grande maioria dos julgados dos tribunais, seguindo um exemplo:

Responsabilidade Civil ... Banco - Cofre Arrombado -
Força Maior - Ônus da Prova. Cofre bancário. Contrato de
locação. Arrombamento. Alegação de força maior. Onus da
prova. Inadimplido o contrato de locação de cofre bancário,
pelo arrombamento e subtração dos valores nele
depositados, compete ao locador, que quer excluir sua
responsabilidade, face à natureza do contrato e o dever de
vigilância insito no mesmo, comprovar cabalmente que o
roubo não poderia ter sido evitado uu impedido e que o
mesmo não pode ser imputado às falhas do serviço. que ele
se obrigou a prestar. Sum essa prova cai no vazio a
alegação da excludente da força maior. ${ }^{\$}$

Mesmo para aqueles que defendem a não aplicação do $C D C$ às operações financeiras admitem a exceção do serviço de aluguel de caixa forte por ser esta uma obrigação de fazer. Portanto, esta figura contratual esta pacificada quanto à aplicação dos dispositivos do CDC.

97 GOMES, Orlando. Contratos. 18. ed. Rio de Janeiro: Forense, 1999. p. 337.

98 TRIBUNAL DE JUSTIÇA DO RIO GRANDE DO SUL. Ac da $5^{2}$ C Civ do TJRJ - rel. Des. Marlan de Moraes Marinho. In: Repertório IOB de jurisprudencia. I" quinzena de abril de 1996. n. ${ }^{2} 7 / 66$, p. 116. $3 / 11854$. 


\subsection{Contrato de empréstimos em suas várias espécies}

É uma das mais antigas figuras bancárias, sendo até mesmo considerada a primeira forma de atividade bancária. Já no Direito Romano, os banqueiros, então denominados de argentari, costumavam emprestar dinheiro mediante a cobrança de juros.

Até mesmo na Idade Média, com a condenação de tal atividade pela Igreja Católica, este contrato não foi abalado. Nesta época, os judeus eram quem mais realizavam este tipo de contrato. ${ }^{99}$

Este tipo de contrato é outra figura muito comum no cotidiano das instituições financeiras, e através desta operação bancária, as instituições obtêm grande parte de seu lucro, pois cobram juros (muitas vezes exorbitantes) e só elas estão autorizadas a realizar tal operação.

O mútuo, ou empréstimo de consumo, ${ }^{100}$ segundo o art. 586 do CC/02, é entendido como o empréstimo de coisas fungíveis ou consumíveis, em que tendo função econômica, os juros são presumidos (art. 591 do CC/02). Esta última modalidade é a mais comum para os Bancos, pois o dinheiro é um bem fungivel e, juridicamente consumível nos moldes do art. 86 do $\mathrm{CC} / 02$, e tendo fins econômicos, os Bancos cobram altos juros.

De acordo com a formidável doutrina francesa, o crédito não é uma noção jurídica precisa. Há diversos contratos através dos quais se permite realizar uma operação de crédito aos consumidores. Podendo ser classificadas em três categorias: a) créditos sem afetação determinada, ou seja, é o empréstimo de dinheiro mediante a cobrança de juros, em que o consumidor utilizará este crédito para suprir quaisquer necessidades; b) créditos pré-afetados, isto é, o financiamento de um determinado produto ou serviço, neste caso, o uso do crédito já está determinado de ante mão; e c) créditos pós-afetados, em que não há uma determinação quanto ao uso do crédito previamente ou ao mesmo tempo em que este é concedido, após esta concessão é que o consumidor irá empregar o crédito obtido para a aquisição de determinado produto ou serviço, como ocorre, por exemplo, nos cartões de crédito (comum) e nos de crédito renováveis ou rotativos. ${ }^{101}$

Pormenorizando, o empréstimo será comercial, quando o tomador deste for pessoa física ou jurídica cuja finalidade é reverter ou utilizar o empréstimo na sua

99 COVELlo. Sírgio Carlos. op. cit., p. 152.

100 Id. Ibid., p. 151 .

101 CALAIS-AUI OY. Jean et al. op. cit., p. 311317 
atividade profissional. Em assim sendo, este contrato seguirá os dispostos do então vigente Código Civil.

Entretanto, se a relação for de consumo, ou seja, se o contratante for um consumidor que utilizará o empréstimo para comprar bens ou serviços necessários à sua subsistência e de sua familia, o contrato seguirá as normas e principios do CDC.

Cabe ressaltar a posição dos respeitáveis doutrinadores, como Edilson Pereira Nobre $\mathrm{Jr}^{102}$ para quem nos contratos de mútuo só exclui a aplicação do CDC, se o mutuário tomar quantia e emprestá-la a terceiros. Neste caso não se pode falar em relação de consumo, não é destinatário final. Entretanto, se o mutuário empregar o valor recebido em sua produção ou para seu consumo, este contrato com uma instituição financeira deverá cumprir os dispositivos do CDC.

O Autor cita como exemplo uma empresa de factoring que toma emprestadas quantias dos Bancos para repassar a terceiros, cobrando altas taxas de juros, estas se destinam ao pagamento dos juros devido aos Bancos e, além de auferir lucro com tal atividade. Portanto as empresas de factoring não poderão valer-se das normas do CDC em eventual litígio contra os Bancos.

Conclui-se que os contratos de empréstimos ora serão de natureza empresarial, ora de natureza consumerista.

O contrato de mútuo pode ser gratuito, ou oneroso. Este último é a regra nos contratos com instituições financeiras, pois tendo fins econômicos, são devidos os juros, onerando desta forma o contrato. É o que se pode observar com o trecho da obra de Arnaldo Rizzardo: ${ }^{113}$

Os Bancos empregam considerável parcela dos valores que arrecadam do público em geral para a concessão de empréstimos aos seus clientes, a prazo fixo, com juros $e$ comissões, o que permite aos mesmos o investimento nos mais variados setores da atividade em que atuam. (grifo nosso)

Configura-se no caso a remuneração direta e indireta, sendo o mutuário um indivíduo que utilizará o crédito obtido em proveito próprio, configura-se uma relação de consumo, e, portanto, indiscutível a aplicação do CDC. Este entendimento está pacificado na jurisprudência:

Contrato de financiamento bancário - Nulidade de cláusulas . Aplicação do Código de Defesa do Consumidor - [...] Tratando-se de empréstimo tomado por consumidor final, a operação crediticia realizada pelo Banco submete-

102 CALAiS-AULOY, Jean et al. op. cit.p. 72.

103 Id. Ibid.. p. 37. 
se às disposições do Código de Defesa do Consumidor, na qualidade de prestador legal. ${ }^{104}$

É cediço que este tipo contratual passou ser figura comum nas relações entre uma instituição financeira e um indivíduo (consumidor), que não dispondo de recursos disponíveis para comprar determinada coisa fundamental para o seu sustento e de sua família, através deste contrato a instituição financeira the adianta o valor, e em contrapartida, o cliente geralmente oferece o próprio bem em garantia pelo não cumprimento do contrato. Assim, está também caracterizada a possibilidade de existir o elemento teleológico da relação de consumo do art. $2^{\circ}$ do CDC: destinação final.

Nery ${ }^{105}$ afirma não existir dificuldades em classificar estes contratos como relação de consumo, pois o objeto destes contratos de financiamento é o empréstimo de dinheiro para o consumidor poder adquirir produtos e serviços no mercado de consumo, sendo, portanto, o destinatário final do "empréstimo" Portanto nada impede que este contrato configure uma relação de consumo, ao contrário, tem sido um meio largamente utilizado pelos consumidores que necessitam de um adiantamento de recursos. Quanto a estes contratos dispõe o CDC nos artigos 52 e seguintes que tratam da concessão de crédito e financiamento

Os contratos de financiamento podem estar vinculados à compra de um bem ou à prestação de determinados serviços, neste caso, Arnold Wald ${ }^{106}$ sustenta a aplicação do dispositivo no art. 52 do CDC. Entretanto, afirma o autor que se o financiamento for livre ou desvinculado não será uma relação de consumo, não se aplicando portanto as normas do CDC. ${ }^{107}$

Todavia estes contratos são, via de regra, um instrumento que possibilita um consumo de determinado produto. Exemplo desta situação é o sistema financeiro da habitação, em que uma instituição financeira antecipa valores ao cliente que visa com tal quantia comprar sua casa própria. Estes tipos de contratos são destinados às pessoas que não têm casa própria, o que revela o alto grau de vulnerabilidade e hipossuficiência destas pessoas face às instituições financeiras. Ressalta-se a posição da jurisprudência: ${ }^{108}$

Contrato de Abertura de Crédito para Construção de Unidade Habitacional com Hipoteca Adjeta. Relação de consumo. Foro de eleição que implique dificuldade de

10s SUPERIOR TRIBLNAL DE JUSTIÇA. REsp n² 213825/RS, Min. Barros Monteiro, j. 22.08.2000.

105 Defesa do Consumidor ... op. cit., p. 196.

106 O direito do consumidor..., op. cit.. p. 17.

107 Contra: CALAIS-AULOY, Jean. op. cit., p. 312; MARQUES. Cláudia Lima. Contratos ..., op. cit., p. 462 463, entre outros.

108 TRIBUNAL DE JUSTIC.A DO DISTRITO FEDERAL. $3^{a}$ T. Civ. - TJDF - AgIn n ${ }^{\circ}$ 2001.00.2.003407-7 j. 08.10.2001 - Rel. Des. Wellington Medeiros. In: Revista de Direito do Consumidor. n." 42/ 328 - 331 , abr./jun. de 2001 . 
acesso à Justiça pelo consumidor. Possibilidade de declinação da competência, de oficio, pelo magistrado. Hipótese excepcional de competência absoluta do juízo do domicílio do devedor.

Em suma para caracterizar o contrato de financiamento como um contrato de consumo, será necessário analisar cada caso em concreto, verificando os elementos essenciais de uma relação de consumo.

Conclui-se que esta modalidade contratual é uma operação complexa, pois tem elementos do contrato de mútuo e de depósito, por isso pode-se dizer que a natureza jurídica deste contrato é atípica, isto é, é uma figura contratual autônoma. ${ }^{109}$

No art. 52 do DCD que trata de outorga de crédito ou concessão de financiamento ao consumidor, estabelece como requisitos, a obrigação da instituição financeira (fornecedor) informar o consumidor sobre: 1. o preço em moeda nacional: 2. os juros de mora e a taxa efetiva de juros anuais: 3 . os acréscimos que a lei permite; 4 . a quantidade e periodicidade das prestações; 5. a soma total a pagar. com e sem financiamento;

Além disso. o $\S 1^{\circ}$ deste artigo fixa as multas de mora, que decorrem do inadimplemento da obrigação no modo e tempo avençados, em não superior a $2 \%$ do valor da prestação.

No sistema português, há uma previsão de uma taxa de juro fixada pelo Ministro das Finanças, e está atrelada à taxa de juro praticada pelas instituições de crédito, acrescida de 1,5\% (vendas a prestação até um ano) ou de $1,75 \%$ (vendas a prestações superiores a um ano). Mas o total dos juros e encargos não pode ultrapassar os $12 \%$ da taxa de desconto do Banco emissor. ${ }^{110}$ Este limite que existia no ordenamento jurídico brasileiro foi revogado pela Emenda Constitucional n. 40/2003.

$\mathrm{O} \S 2^{\circ}$ do mesmo artigo faculta ao consumidor o pagamento adiantado da divida, mas neste caso prevê uma redução proporcional dos juros e demais acréscimos.

É comum, entretanto, a emissão de notas promissórias assinadas em branco pelo cliente como garantia do crédito concedido. Esta prática é, todavia, abusiva segundo os dispositivos do CDC que obriga ao fornecedor informar ao consumidor sobre os serviços e produtos oferecidos e os preços dos mesmos (art. 52). ${ }^{11}$

\footnotetext{
109 GOMES, Orlando. op. cit., p. 327.

110 ALMEIDA, Carlos F. de. op. cit., p. 149.

i' RIZZARDO, Arnaldo. op. cit., p. 60-61.
} 
Quanto à modalidade de crédito rotativo, a mais comum é a abertura de crédito em conta corrente, podendo ser enquadrada como uma relação de consumo, é o que se percebe pela análise do julgado do Tribunal de Alçada do Rio Grande do Sul: ${ }^{112}$

Contrato de Abertura de Crédito em Conta Corrente Execução por título extrajudicial - Inadmissibilidade Instrumento acompanhado de extratos da conta Irrelevância - Descabimento da instituição de crédito criar seus próprios títulos. Ementa da Redação: O contrato de abertura de crédito em conta corrente, ainda que acompanhado dos respectivos extratos de movimentação da conta, não é título executivo extrajudicial, sendo inviável sua execução e impossível o título completar-se com extratos unilaterais, pois não é dado às instituições de crédito criar seus próprios títulos, o que é prerrogativa da Fazenda Pública.

A posição do STJ tem sido neste sentido, isto é, não considera o contrato de abertura de conta corrente como um título executivo extrajudicial, e a nota promissória por si só não revela a existência da dívida, devendo-se preceder um processo de conhecimento para que o juiz avalie a existência e o valor da dívida no caso concreto.

Quanto aos possíveis valores debitados indevidamente da conta do consumidor, este terá direito à repetição do indébito em dobro segundo o art. 42 do CDC.

Aplica-se o CDC a estes contratos sempre que configure uma relação de consumo, ou seja, se o cliente é o destinatário final da conta corrente. ${ }^{113}$ Este é o entendimento majoritário, conforme o acórdão infra:

Contrato de Abertura de Crédito. Incidência do Código de Defesa do Consumidor. Arts. 535 e 458, III, do CPC e 115 e 145 do CC. Capitalização. Súm. 30 da Corte. ${ }^{1 / 4}$

\section{Conclusão}

Diante da importância que os contratos bancários exercem na sociedade pós-moderna, numa sociedade "bancarizada" é necessário que o Estado imponha direitos e deveres através de normas cogentes como o fez promulgando o Código de

\footnotetext{
112 4² Câm.do TARS, Ap. n. 196.099.337, j. 22.08.1996, Rel. Juiz Henrique Osvaldo Poeta Roenick. In: Revista dos Tribunais, n.. 734/488-489, dezembro de 1996.

113 EFING, Antônio Carlos. op. cit., p. 107.

14 SUPERIOR TRIBUNAL DE JUSTIC:A. REsp n. 277.389 - RS - 3a T. - STJ - j. 12.06.2001 - Rel. Min. Carlos Alberto Menezes Direito. In: Revista de Direito do Consumidor, n. $42 / 317$-319, abr/jun. de 2002.
} 
Defesa do Consumidor para efetivar a igualdade real entre os contratantes e necessário equilibrio contratual.

O CDC estrutura-se adotando o princípio da vulnerabilidade do consumidor (art. $4^{\circ}$ ), esta vulnerabilidade é incontestável nas operações bancárias, agravada pela essencialidade destes contratos (contratos cativos de longa duração). Por isso, o CDC, no $\S 2^{\circ}$ do art. $3^{\circ}$. diz expressamente que as normas consumeristas aplicamse, inclusive, nas atividades fomecida no mercado de consumo de natureza bancária, financeira e de crédito.

Todavia, o lobby' das instituições financeiras, desde a promulgação do CDC, luta arduamente para se eximirem da aplicação deste Estatuto, e em 26/12/2002 entrou com uma Ação Direta de Inconstitucionalidade (ADIn n. 2.591), alegando que ser inconstitucional a expressão: "inclusive as de natureza bancária, financeira, de crédito e securitária" contida no $\S 2^{\circ}$ do art. $3^{\circ}$ do CDC.

Tomando por base outros países como Inglaterra (Consumer C'redit Act 1974), Estados Unidos (Uniform Consumer Credit Code e Consumer Credit Protection Act - 1968), Suécia, Portugal, França (Loy 78-22, de 10.01.1978 - Code de la Consommation) e toda a Comunidade Européia (Dir. 87/102, de 22.12.1986), as regras de defesa dos direitos dos consumidores é acentuada face às instituições financeiras, cuja finalidade é protegê-lo dos "perigos do crédito"

Os Bancos são essencialmente fornecedores na concepção do art. $3^{\circ}$ do CDC, porque exercem profissionalmente suas atividades através de operações remuneradas direta ou indirctamente. Direta através da cobrança de taxas para executar determinados serviços; e indireta representada pela retenção de valores ("float").

Sendo assim, deve-se o intérprete verificar no caso concreto se o consumidor das operações bancárias utilizam ou não estes serviços c produtos como destinatário final conforme o art. $2^{\circ}$ do CDC.

Na delimitação do conceito de consumidor há duas correntes doutrinárias, a Maximilista, que defende a ampla aplicação do CDC já que é uma norma destinada à sociedade de consumo. E a Finalista que interpreta o conceito de consumidor restritivamente, ou seja. se utiliza o produto ou serviço como destinatário final, retirando-o do mercado de consumo.

O CDC é um microssistema jurídico que encerra um novo contexto para as relações de consumo em que os princípios da Teoria Clássica Contratual não são mais absolutos diante dos princípios inovadores trazidos pelo CDC, como o princípio da vulnerabilidade, da boa-fé objetiva, da responsabilidade objetiva pelo risco da atividade. Com a promulgação do $\mathrm{CC} / 02$, cujas diretrizes entre outras são eticidade e socialidade 
do direito, há uma semelhança muito grande entre os princípios contratuais no CDC e os do CC/02. Todavia, o CDC continua sendo o diploma legal que regula as atividades essencialmente profissionais, como a publicidade e as práticas comerciais abusivas.

Após estas considerações gerais, tendo em vista as variadas espécies de contratos e serviços bancários o CDC é constitucionalmente o Estatuto aplicado (art. $5^{\circ}$ inciso XXII; art. 170, inciso V; art. 48 do ADCT). Neste breve estudo foi analisado alguns destes contratos e serviços bancários, a saber: contrato de abertura de conta corrente, contrato de poupança, caixas de segurança ou cofres individuais, contrato de empréstimos em suas várias espécies. E verificou-se que estas operações são realizadas profissionalmente pelos Bancos que auferem seus lucros através delas.

Nery $^{115}$ afirma que excluir as instituições financeiras do sistema de proteção ensejado pelo CDC é "remar contra a maré, é andar na contra-mão da história e da economia mundial" Portanto, a doutrina predominante é no sentido de incluir os serviços e produtos no rol de proteção do $\mathrm{CDC}$, desde que o cliente os utilizem ou adquirem como destinatário final, isto é, não relacionado com sua atividade profissional ou empresarial. ${ }^{116}$

O CDC quer proteger e tutelar os direitos dos mais fracos e vulneráveis (econômica, social, cultural, técnica, jurídica etc), coisa bem comum diante à contratação em massa e a imposição de cláusulas e condições gerais dos contratos pelos Bancos.

Seria um absurdo a não aplicação do CDC aos Bancos, e desta forma eles poderiam inserir nos contratos cláusulas extremamente abusivas, violando as normas constantes do art. 51 do CDC, além de poderem veicular propagandas enganosas e abusivas sem nenhuma sanção. ${ }^{117}$

Feriria o princípio da razoabilidade e proporcionalidade se isentando os Bancos da aplicação das normas do CDC, não se aplicassem normas de conduta como: a) coibir cobranças indevidas (art. 39, V e art. 42, §ún.); b) punir falhas em transações eletrônicas (art. $6^{\circ}$. VI e art. 20); c) punir pela inclusão indevida em cadastros de inadimplentes (art. 39, V, art. 42 e art. $43, \S 1^{\circ}$ ); d) coibir cláusulas contratuais abusivas (art. 51): e) punir práticas comerciais abusivas como o envio de produto sem prévia solicitação (art. 39, III) ou-não entrega do contrato (art. $6^{\circ}$ III e art. 46); f) obrigatoriedade do desconto na liquidação antecipada de financiamento (art. 52, $\S 2^{\circ}$ ); g) facilitação da defesa em juízo (art. $6^{\circ}$, VIII); h) proibir a venda casada (art. 39, I), dentre outros.

\footnotetext{
115 A defesa ... op. cit.. p. 200. No mesmo sentido: BASSO E SIL.VA, Ederson Ribas. Op. cit.

116 ZANLLLLATO. Marco Antônio. op. cit., p. 37.

117 LUCCA, Newton de. op. cit., p.79 - 80.
} 
Un sistema democrático pressupõe a proteção dos pais fracos. que são os mais numerosos, contra a força de outros. Esta deve ser a ótica da proteção dos consumidores que contratam com as instituições financeiras. ${ }^{118}$

Para dar maior eficácia aos direitos contidos no CDC, é mister que este tenha total aplicação, inclusive os consumidores de crédito e serviços bancários, restabelecendo assim o equilíbrio entre as partes.

São Paulo, fevereiro de 2006.

\section{Referências}

ALMEIDA, Carlos Ferreira de Almcida. Os direitos dos consumidores. 1. ed. Coimbra (Portugal): Almedina, 1982.

ARIDA, Pérsio. Direito e Economia. FG $V^{\prime}$ Edesp, São Paulo, visāo revisada em 10.10.2003.

BASSO E SILVA, Ederson Ribas. A inversão do ônus da prova nos contratos bancários á luz do CDC. In LUX JORNAL - O Estado do Paraná, Curitiba, PR. Publicado em 06/05/200I.

BENJAMIN, Antônio Herman de Vasconcellos e. [et al]. Código Brasileiro de Défesa do Consumidor: 6. ed. Rio de Janeiro: Forense L'niversitária, 1999.

BRINDEIRO. Geraldo. Parecer à ADIn n. 2.591. Disponivel em: <http://www.brasilcom.org.br $>$. Acessado em: 20 de dezembro de 2004.

CALAIS-AUlOY. Jean: STEINMET7. Frank. Droit de la consommation. 4. ed. Paris: Dalloz. 1996.

CAMPILONGO, Celso Fernandes. O Direito na sociedade complexa. São Paulo: Max Limonad. 2000.

CARVAlho FILHO, José dos Santos. Manual de direito administrativo. 10 ed. Rio de Janeiro: Lumen Juris, 2003.

CAVALIERI Filho, Sérgio. Responsabilidade civil das instituições bancárias por danos causados a correntistas e a terceiros. Revista de Direito do Consumidor, São Paulo, n. 34. p. 102-110. abr. jun. 2001.

COVEllo. Sérgio Carlos. Contratos bancarios. 4. ed. rev. e atual. São Paulo: Liv. e Ed. Universitária de Direito, 2001.

118 RIPERT, Georges. op. cit.. p. 4950 
DALL'AGNOL Jr.. Antônio Janyr. Direito do consumidor e serviços bancários e financeiros aplicação do CDC nas atividades bancárias. Revista do Direito do Consumidor; São Paulo, v. 27, p. 07-17, jul./set. 1996.

DERANI, Cristiane. Novo parecer sobre a ADIN n. 2.591, de 26 de dezembro de 2002. Disponível em: <http://www.brasilcom.org.br>. Acessado em: 19 janeiro 2005.

DONATO, Maria Antonieta 7anardo. Proteção do consumidor - conceito e extensão. São Paulo: Revista dos Tribunais, 1993.

EFING, Antônio Carlos. Contrutos e Procedimentos à luz do Código de Defesa do Consumidor: 1. ed., 3. tir. São Paulo: Revista dos Tribunais, 2000

GOMES, Orlando. Contratos. 18. ed. Rio de Janeiro: Forense, 1999.

LEÃES, Luiz Gastão Paes de Barros. As relações de consumo e o crédito ao consumidor. Revista de Direito Mercantil. n. 82, p. 13-23, abril/junho 1991.

LUCCA, Newton de. A aplicação do Código de Defesa do Consumidor à atividade bancária. Revista de Direito do Consumidor, São Paulo, v. 27, p. 78-87, jul./set. 1996.

O Código de Defesa do Consumidor: discussões sobre seu âmbito de aplicação. Revista de Direito do Consumidor, São Paulo, n. 6, p. 66-68.

MACEDO Jr., Ronaldo Porto. Contratos relacionais do direito bancário. (Palestra proferida no $1^{\circ}$ Simpósio Nacional de Direito Bancário, realizado em São Paulo de 06 à 08 de Julho de 2000. Disponivel em: <http://www.cartamaior.uol.com.br/doutrina/exibe_artigo.asp?cd_artigo=77>. Acessado em: 11 janeiro 2005.

MARINS, James. Proteção contratual do CDC a contratos interempresariais, inclusive bancários. Revista de Direito do Consumidor, São Paulo, v. 18, p. 94-104. abr./jun. 1996.

MARQUES, Cláudia Lima; BENJAMIN, Antônio Hernan V.; MIRAGEM, Bruno. Comentários ao Código de Defesa do Consumidor: arts. $1^{\circ}$ a 74 - Aspectos Materiais. São Paulo: Revista dos Tribunais, 2003.

. Contratos bancários em tempos pós-modernos- primeiras reflexões. Revista de Direito do Consumidor, São Paulo, v. 25, p. 19-38, jan./mar. 1998.

Contratos no Código de Defesa do Consumidor: o novo regime das relações contratuais. 4. ed. rev. atual. e ampl. São Paulo: Revista dos Tribunais, 2002.

Parecer para a ADIn 2.591 a pedido do Brasilcom. Disponível em: $<$ http://www. brasilcom.org.br>. Acessado em: 10 dezembro 2004. 
NLEY JUNIOR, Nelson. Defesa do consumidor de crédito bancário em juizo. Revista de Direito Privado, São Paulo, n. 05. p. 192-222, jan./mar. 2001.

Os principios gerais do Código Brasileiro de Defesa do Consumidor. Revista de Direito do Consumidor, São Paulo, n. 03, p. 44-77, set./dez. 1992.

[et al]. Código brasilciro de defesa do consumidor: comentado pelos autores do anteprojeto. 6 ed. Rio de Janeiro: Forense Universitária, 2000.

NOBRE JR.. Edilson Pereira. A proteção contratual no código do Consumidor e o âmbito de sua aplicação. Revista de Direito do Consumidor, São Paulo. n. 27. p. 57-77. jul./set. 1996.

PASQualotTO, Adalberto. Conceitos fundamentais do Código de Defesa do Consumidor. Revista dos Tribunais, São Paulo, n. 666, p. 48-53, abril 1991.

PFFIFFER, Roberto Augusto Castellanos. Constitucionalidade da submissão dos serviços de natureza bancária, financeira, de crédito e securitária ao Código de Defesa do Consumidor. Disponível em: <http: www.brasilcom.org.br>. Acessado em: 05 de janeiro de 2005.

REALE, Miguel. Lições preliminares de Direiro. 24. ed. São Paulo: Saraiva, 1998.

RIPERT, Georges. Aspectos juridicos do capitalismo moderno. Tradução Gilda G. de Azevedo. São Paulo: Freitas Bastos, 1947.

RIZZARDO, Amaldo. Contratos de crédito bancário. 5. ed. rev., atual. e ampl. São Paulo: Revista dos Tribunais, 2000.

ZANELlATO, Marco Antônio. Considerações sobre o conceito juridico de cansumidor. Revisła Estratégica - Revista da Faculdade de Administração FAAP e do FAAP - MBA, v. 1, n. 2, p. 3445, julho/setembro. 2002.

WALD. Arnold. O direito do consumidor e suas repercussões em relação às instituições financeiras. Revista dos Tribunais, v. 666, p. 07-17. abril 1991. 